\title{
ALIMENTACIÓ I ASCETISME ALS SEGLES VI I VII. ANÀLISI COMPARATIVA \\ D'ALGUNS MODELS DIETĖTICS MONACALS \\ ITALIANS I IBÈRICS
}

\author{
ANTONI RIERA I MELIS \\ Universitat de Barcelona
}

\begin{abstract}
SUMARI
1. Introducció.- 2. El triomf social de la carn.- 3. La discordança monàstica: a. El sistema alimentari comú. b. Els règims especials. c. La carn i el vi en les dietes dels monjos. d. Rerafons clàssic i patrístic de la dietètica monàstica.- 4 . Conclusions.
\end{abstract}

\section{INTRODUCCIÓ}

El monacat cristià és una creació de l'Antiguitat tardana. Durant l'època del Baix Imperi Romà, alguns fidels, a Orient, es van retirar de la societat, van renunciar als plaers del cos, per a concentrar-se en el conreu de la virtud i de la perfecció espiritual. Les àrees elegides van ser els deserts que vorejaven la vall del Nil, des de la Tebaida, a Núbia, fins a les rodalies d'Alexandria, al Delta. D' Egipte provenen els codis de Pacomi i de Basili el Gran, els primers que van regular la vida ascètica en comú. El nou corrent espiritual es van expandir ràpidament, des del 350 ençà, cap a Palestina i l'Occident. En la introducció del cenobitisme a Itàlia, la Gàl·lia, Germània i Hispània, va jugar un paper important un conjunt de monjos orientals com Joan Cassià, Atanassi o Martí de Dumio, que hi van fundar monestirs. Aquesta dependència palesa envers les normes egípcies, palestines o siríaques es van prolongar fins a mitjan segle VI, quan es van redactar les

"Anuario de Estudios Medievales", 28 (1998) 
primeres regles occidentals conegudes, síntesis més o menys reeixides de l'experiència antiga i de l'espiritualitat local coetània. Cesari d'Arle, Aurelià, Colombà, Benet de Núrsia, Férreol d'Uzés, Leandre i Isidor de Sevilla, Donat, Walbert de Luxeuil, Fruitós de Braga són els autors més coneguts d'aquestes primeres generacions de compiladors occidentals de costums monàstics. A la llista anterior - merament indicativa- s'han d'afegir encara dues importants regles anònimes, la del Mestre i la Común, de provinença no ben establerta la primera i galaica la segona.

Tots els mestres d'ascetisme van concedir a l'alimentació la importància que es mereixia. Conscients de la influència que el règim tenia sobre l'activitat intel-lectual i el comportament humà, van assentar les bases -conjuntament- d'una autètica dietètica monàstica. Per tal d'obviar la superficialitat i no conferir una extensió excessiva a aquest article, he procurat acotar amb força precisió el camp d'estudi. No he analitzat el contingut alimentari de tots els codis esmentats sinó només el d'un selecte conjunt: l'integrat per la norma italiana de Benet de Núrsia, la més important de tot l'Occident postclàssic, i per les regles hispanes de Leandre i Isidor de Sevilla, de Fruitós de Braga i Común.

Qualsevol règim alimentari és deutor del passat $\mathrm{i}$ indissociable del present; no és mai un sistema tancat, que conté totes les claus explicatives de la pròpia complexitat. D'acord amb aquesta premissa metodològica, no em limitaré a descriure els primers models dietètics creats pel monacat occidental, intentarè, a més, reconstruir-ne el substrat teòric comú i els relacionaré amb els seus respectius contexts culturals.

\section{EL TRIOMF SOCIAL DE LA CARN}

Des del segle $\mathrm{V}$, com a conseqüència de l'esfondrament de les estructures agràries romanes i la influència dels pobles germànics, la carn esdevé, arreu de l'Occident, un aliment d'alt valor. Els recels que havia suscitat entre un sector força representatiu de la intel-lectualitat llatina, que es considerava hereu de l'àntic estoïcisme ${ }^{\prime}$, desapareixen ràpidament durant l'etapa inicial de l'Alta Edat Mitjana, quan la vella noblesa senatorial és

\footnotetext{
'Que havia relegat la carn a la condició d'aliment complementari i havia defès un tipus de relació home/dieta inspirat sobretot en el concepte de l'equilibri, de la mesura.
} 
eclipsada políticament per la nova aristocràcia militar ${ }^{2}$. Si la medicina romana considerava el pa com el millor comestible, per tal com contenia - segons Cornelio Celso- "més substància nutritiva que cap altra vianda"3, la dietètica postclàssica concedirà molta més importància al tall.

La carta De observatione ciborum que Antimo, un metge italià de formació greca, va dirigir, el primer terç del segle VI, a Teodoric I, rei dels francs ${ }^{4}$, reflecteix clarament la revalorització experimentada per la carn. El representant dels nous corrents bromatològics concedeix una atenció preferent als comestibles d'origen animal; descriu les propietats nutritives i les millors maneres de preparar les carns de porc, vaca, bou, ovella, xai, cabrit, cérvol, isard, senglar, llebre, faisà, perdiu, colom, paó, gallina i $\mathrm{oca}^{5}$. A les cuines dels estaments privilegiats, a l'etapa inicial de l'Edat Mitjana, es manipulaven quotidianament, doncs, carns de textures, gustos i provinença molt diversos. La ramaderia i la caça majors i menors asseguraven als poderosos un abastament fluid i diversificat de proteïnes i greixos. Pel que fa a les preparacions, l'esmentada font ens informa que la carn apareixia a taula rostida, al forn, guisada, bullida, fregida o crua ${ }^{6}$. Antimo només recomana restringir el consum de la carn crua, per tal com és força indigesta ${ }^{7}$. L'ensunya més noble sana i adient per a tota mena de plats és el

\footnotetext{
${ }^{2} \mathrm{M}$. Aurell, La noblesse en Occident $\left(V^{\prime}-X V^{\prime}\right.$ siècle), Paris, Armand Colin, 1996, pp.10-28

${ }^{3}$ De medicina, II, 18; cit. M. MONTANARI, El hambre y la abundancia. Historia y cultura de la alimentación en Europa, Barcelona, Crítica, 1993, p. 24, nota 34.

${ }^{4}$ Un text que per la seva originalitat ha atret l'interès dels historiadors de la medicina, com es desprèn de les seves diverses edicions: V. Rose, Leipzig, B.G. Teubneri, 1877; Sh. H. Webern, Leyden, J. Brill, 1924; E. Liechtenhan, Leipzig, B.G. Tevbneri 1928; A. Marsili, Pisa, U. Giardini, 1959. De la carta d'Antimo disposem també d'algunes traduccions a l'italià: G. GENTILLI, Il medico bizantino Antimo (VI secolo) e la sua epistola "De observatione ciborum", "Atti del XVI Convegno Nazionale della Società Italiana di Storia della Medicina", Bologna-Ravenna, 1959, pp. 212-233; A. Marsili n'inclou una altra al final de la seva edició, pp. 37-137. Aquest breu $i$ interessant tractat dietètic ha estat molt ben estudiat per Massimo MONTANARI, Alimentazione e cultura nel Medioevo, Roma-Bari, Laterza, 1988, pp. 206-208; IDEM, El hambre y la abundancia, pp. 24-25.

${ }^{5}$ Ed. V. Rose, pp. 9-14; ed. E. Liechtenhan, pp. 4-16; ed. A. Marsili, pp. 46-85. M. MONTANARI, Alimentazione e cultura, p. 207; IDEM, El hambre y la abundancia, pp. 24-25.

${ }^{6}$ Ibidem.

7"Prima sanitas ex cibis bene coctis et bene digestis constat... nam sí necessitas exierit carnes uel alia crudiora manducare, non ad nimietatem, sed parcius": Ed. V. ROSE, p. 8; ed. E. Liechtenhan, p. 2; ed. A. MARSILI, p. 18.
} 
llard $^{8}$. L'oli d'oliva, tan apreciat pels romans de totes les categories socials ${ }^{9}$, ha esdevingut, entre els segles IV i VI, el greix dels pobres ${ }^{10} i$ dels ascetes ${ }^{11}$.

L'estima per la carn arrela amb força en el conjunt de la societat laica, des dels restringits cercles dels poderosos, a les taules dels quals apareix abundament gairebé cada dia, fins als amplis estaments subalterns, que anhelaven augmentar-ne el consum. Per primera vegada en molt de temps comença a qüestionar-se la supremacia del pa com a eix i símbol dels sistemes alimentaris occidentals, inclosos els mediterranis ${ }^{12}$.

El sentit de la mesura, de la proporció, que havia caracterizat la cultura clàssica, s'esvaeix, arran de la caiguda de l'Imperi d'Occident, i és substituiit per unes pautes de conducta inspirades en l'excés ${ }^{13}$. Entre l'aristocràcia guerrera de l'Alta Edat Mitjana, per influència del paganisme germànic, la força física, la violència, l'"animalitat"14 de l'home gaudien d'un gran prestigi, eren considerades com a elements essencials de la noblesa i del poder. A poc a poc, durant els segles VI i VII, la nova cultura aristocràtica conforma uns models de vida, uns plantejaments mentals i uns patrons ètics que identifiquen l'home noble, valent $\mathrm{i}$ fort amb aquell que menja molt i, sobretot, carn ${ }^{15}$. Gregori de Tours ens ha conservat una bona imatge de la bulímia ostentosa dels nobles gals de mitjan dels cinc-cents al

\footnotetext{
${ }^{8} \mathrm{~A}$ les virtuts dietètiques i gastronòmiques del qual Antimo dedica el capítol més llarg de l'epístola, el catorzè: Ed. V. Rose, p. 11; ed. E. LIEChTENHAN, pp. 8-10; ed. A. MARSILI, p. 22.

${ }^{9}$ Com ho palesa l'únic -i tardà- receptari que ens ha arribat, L'Art de la cuina, d'Apici; ed. i trad. Joan GómEZ I PALlarès, Barcelona, Fundació Bernat Metge, 1990, pp. 43, 47, 54, $82,83,84,88,89,95,99,109,113$ i 128.

${ }^{10}$ Masona, bisbe de Mèrida, en repartia periòdicament, a mitjan segle VI, entre els pobres de la ciutat i de la rodalia: "Si quis vero de civibus urbis aut rusticis de ruralibus ad atrium ob necessitatem acessisset, liquorem vini, olei vel mellis a dispensatibus poposcisset, et vas parvulum in quo levaret exhibuisset et eum vir sanctus vidisset, ut erat semper obtuto gratus iocundo vultu, mox ipsum vasculum confrigi et ut maiorem deferret praecipiebat": Vitas Sanctorum Patrum Emeritensium, ed. J.N. Garvin, Washington, 1946, p. 194. Les institucions assistencials de l'església de Mèrida - força originals- han estat analitzades per José ORLANDIS a La Iglesia en la España visigótica y medieval, Pamplona, Eunsa, 1976, pp. 224-228.

"Vegeu infra, notes 44 i 76.

${ }^{12} \mathrm{M}$. MONTANARI, El hambre y la abundancia, p. 25.

${ }^{13}$ M. MONTANARI, Alimentazione e cultura, p. 19

${ }^{14}$ Terme encunyat per M. MONTANARI, Alimentazione e cultura, p. 6

${ }^{15}$ M. MonTANARI, L'alimentazione contadina nell'alto Medioevo, Napoli, Liguori, 1992, pp. 455-464. IDEM, Alimentazione e cultura, pp. 7 i 19-20.
} 
passatge de la mort de Parteni: "era molt voraç a taula; digeria de pressa tot allò que menjava, prenia àloe per a recuperar més ràpidament la gana; deixava escapar eructes en públic, sense cap consideració per aquells que els sentien"16. Per als membres de l'estament militar, la prohibició del consum de carn, una necessitat més psicològica que biològica ${ }^{17}$, constitueix un càstig molt greu, amb un fort contingut simbòlic, perquè significa una marginació temporal del col-lectiu dels poderosos, dels forts ${ }^{18}$.

La carn, als confins de l'Antiguitat i l'Edat Mitjana, esdevé, doncs, entre totes les capes socials, el "valor" alimentari per excel-lència, aquell que suscita més atencions materials, d'índole econòmica, i més sol-licituds d'ordre cultural, de natura ideològica, ètica i simbòlica ${ }^{19}$

\section{LA DISCORDANÇA MONÀSTICA}

L'únic col-lectiu que no va participar d'aquesta unaminitat alimentària va ser el dels monjos. Als cenobis prosperaven, aleshores, un model de conducta, una escala de valors ${ }^{20}$ i un comportament alimentari molt diferents dels desenvolupats pels milites, pels potents laics. Els ascetes oposaven el sacrifici al plaer, l'expiació a l'hedonisme, la castedat a la sexualitat, la humilitat a l'altivesa, la caritat a l'interès, el pacifisme a l'agressivitat, la vigília a la son, el silenci a la conversa, el sedentarisme a la vagabunderia, l'obediència al comandament i l'anorèxia a la bulímia. El dejuni i l'abstinència, segons els teòrics de l'ascetisme, eren dos valors excelsos $i$, en conseqüència, els creients, tant els eclesiàstics com els laics, no els havien de practicar com una càrrega inevitable sinó voluntàriament $\mathrm{i}$

\footnotetext{
${ }^{16}$ Histoire des francs, trad. R. Latouche, Paris, Les Belles Lettres I, p. 177.

${ }^{17}$ M. MOnTANARI, Alimentazione e cultura, p. 47.

${ }^{18} \mathrm{M}$. MONTANARI, Alimentazione e cultura, pp. 24-25 i 47

${ }^{19} \mathrm{M}$. MONTANARI, Alimentazione e cultura, p. 53.

${ }^{20}$ Ben resumida als capítols IV, V, VI i VII de La Regla de San Benito [ed. G.M. Colombás i I. ARANGUREN, Madrid, Biblioteca de Autores Cristianos, 1979, p. 82-100], relatius als instruments de perfecció espiritual, a l'obediència, a la taciturnitat $\mathrm{i}$ a la humilitat respectivament. Les virtuts que han de practicar i els vicis que han d'evitar els ascetes apereixen, a les restants normes monàstiques, menys concisaments formulats, espargits per diversos apartats del text.
} 
entusiasta ${ }^{21}$. Aquestes pautes dietètiques alternatives, els defensor de les quals consideraven aptes per al conjunt de la societat, troben l'expressió més plena en les diverses regles monàstiques.

Al segles VI i VII, força abans que l'Administració carolingia no imposés arreu de l'Occident la uniformitat benedictina, cada monestir es regia per unas observances específiques, constituïdes per la combinació d'elements extrets de regles preexistents. Els diversos codis monàstics seleccionats per cada comunitat solien conservar-se en un únic manuscrit, el codex regularum, que esdevenia la font d'inspiració dels seus successius abats. Malgrat que els preceptes recollits continguessin disposicions incompatibles, el mestre d'ascetisme corresponent seleccionava, en cada cas, un conjunt de principis mínimament concordants, amb què construïa una norma provisional, designada sovint com a regula mixta ${ }^{22}$. En els conjunts de codis per què es regien els monestirs italians, no hi solia faltar la Regla de Benet de Núrsia, redactada, entre el 530 i el 560, per als monjos de Montecassino ${ }^{23}$. Aquesta norma, per la seva ponderació i funcionalitat, gaudeix d'un èxit creixent $\mathrm{i}$, des de la Itàlia central, s'estén gradualment per l'Occident $^{24}$, on esdevé àmpliament majoritària abans del 800 . A Hispània, durant el segle VII, els ordes masculins s'inspiren preferentment en la norma

\footnotetext{
${ }^{21}$ Pere Crisòleg, bisbe de Ravenna, un membre del clergat secular, al segon quart del segle $\mathrm{V}$, ja havia recomanat a tots els seus diocesans, no sols als monjos, la renúncia voluntària $\mathrm{i}$ sovintejada dels queviures forts, com una via assequible i efectiva de perfeccionament espiritual: "Ieiunans ita excolit animam, purgat sensus, cor mudat, abscindit uitia, eradicat crimina, dat menti cultum, corpori dat decorem" [Cit. A. OlIVAR, La vida rural i la pastoral reflectides en la predicació de Pere Crisòleg, "Spania. Estudis d'Antiguitat Tardana oferts en homenatge al professor Pere de Palol i Salellas", Barcelona, Abadia de Montserrat, 1996, p. 177].

${ }^{22}$ M. Mundó, Il Monachesimo nella Peninsola Iberica fino al secolo VII. Questione ideologiche e letterarie, "Il Monachesimo nell'Alto Medieovo e la formazione de la Civiltà Occidentale", Spoleto, Centro Italiano di Studi sull'Alto Medioevo, 1957, pp. 95-97. A. Linage, Los orígenes del monacato benedictino en la Península Ibérica, León, Centro de Estudios e Investigación "San Isidoro"-Consejo Superior de Investigaciones Científicas, 1973, I, pp. 99-100.

${ }^{23} \mathrm{G}$. TURBESSI, La Regola di S. Benedetto nel contesto delle antiche regole monastiche, "Erster Internationaler Regula Benedicti-Kongress", Hildesheim, Verlag H.A. Gerstenberg, 1972, pp. 57-90. A. de VoGÜÉ, Saint Benoît en son temps: regles italiennes et regles provençales au VI siècle, "Ibidem", pp. 169-193. IDEM, Autour de saint Benoit. La Règle en son temps et dans le nôtre, Bellefontaine, 1975. J. LECLERCQ, Autour de la Règle de saint Benoit, "Collectanea Cisterciensia", 37 (Scourmont, 1975), pp. 167-204.

${ }^{24} \mathrm{Per}$ a la primera difusió territorial de la Regla benedictina, continua encara essent vàlida la síntesi que va redactar, fa més de trenta-cinc anys, A. LINAGE [Los orígenes del monacato benedictino, I, pp. 112-190].
} 
d'Isidor de Sevilla ${ }^{25}$, a la Bètica, i en el codi de Fruitós de Braga ${ }^{26}$ i la Regla común ${ }^{27}$, a la Galècia; les còmunitats femenines, si més no les de la meitat meridional, es guien sobretot pel precepte de Leandre de Sevilla ${ }^{28}$, quelcom més antic que no els tres anteriors, per tal com la seva redacció ha estat situada pels volts del $580^{29}$. La influència benedicitina, palesa ja en Isidor de Sevilla ${ }^{30}$ i a la Regla común ${ }^{31}$, s'accentua durant la segona meitat del segle VII arreu de la Península Ibèrica, especialment a les costeres mediterrànies. Aquest particularisme monàstic ${ }^{32}$ - una de les nombroses conseqüències del tancament que van experimentar, entre la desaparició i la restauració de l'Imperi a Occident, les Esglésies dels nous regnes germànics, cada cop més desvinculades de Roma- no implica, tanmateix, diferències importants respecte a les excel·lències morals atribuïdes a la frugalitat, a les renúncies alimentàries ${ }^{33}$.

Els mestres d'ascetisme van concedir a l'alimentació una gran importància. Els més conspicus van intuir la influència que el règim tenia sobre l'activitat intel·lectual i el comportament humà, i van dedicar temps i atenció al tema de la dietètica, per tal de dissenyar un sistema alimentari específic, adient a un gènere de vida i a un model moral orientats al domini dels instints dels cos i a la perfecció de l'esperit. Joan Cassià, amb una

${ }^{25}$ Editada per J. CAMpos a SAN LEANDro, SAN Isidoro, SAN Fructuoso, Reglas monásticas de la España visigoda. Los tres libros de las "Sentencias", Madrid, Biblioteca de Autores Cristianos, 1976, pp. 77-125.

${ }^{26}$ Editada per J. CAMPOS a Reglas monásticas de la España visigoda , pp. 137-162.

${ }^{27}$ Editada per J. CAMPOS a Reglas monásticas de la España visigoda, pp. 163-211.

${ }^{28} \mathrm{Pel}$ Libro de la educación de las vírgenes y del desprecio del mundo", editat per J. CAMPOS, "Fbidem", pp. 21-76.

${ }^{29} \mathrm{~J}$. CAMPOS, Introducción al "Libro de la educación de las vírgenes y del desprecio del mundo" de San Leandro, obispo de Sevilla, "Ibidem", pp. 11-12.

${ }^{30}$ A. Mundó, Il Monachesimo nella Peninsola Iberica, p. 102. J. JANINI, San Isidoro y la Regla de San Benito [c. 39,1], "Analecta Sacra Tarraconensia", 31 (Barcelona, 1958), pp. 259260. A. LinAGE, Los orígenes del monacato benedictino, I, pp. 277-285.

${ }^{31} \mathrm{~A}$. LiNAGE, Los origenes del monacato benedictino, I, pp. 285-287.

${ }^{32}$ Ben analitzat per A. LINAGE [El ideal monástico de los padres visigóticos, "Ligarzas", I (València, 1968), pp. 79-97; La condición social y el régimen de trabajo en el monacato visigodo, "Ligarzas", 2 (1970), pp. 5-19; Los orígenes del monacato benedictino, I, pp. 211-291; La enfermedad, el alimento y el sueño en algunas reglas monásticas, "Cuadernos de Historia de la Medicina Española", VI (Salamanca, 1967), pp. 9-22] i J. CAMPOS [Lengua e ideas del monacato visigodo, "Anales Toledanos", III (Toledo, 1971), pp. 219-234].

${ }^{33}$ Regla de San Benito, pp. 82 i 135-139. SAN LEANDRO, Libro de las vírgenes, p. 56. SAN ISIDORO, Regla, pp. 93-94 i 105. SAN FRUCTUOSO, Regla de monjes, pp. 147 i 158. Regla común, p. 180. 
considerable experiència en diversos ambients monàstics i un domini ampli de les fonts literàries, va recollir, cap al 415 , algunes normes sobre la nutrició dels ascetes a les seves Institutiones; arriba a la conclusió que el règim més adequat per a un monjo seria aquell que esmorteís els ardors de la concupiscència, que es pogués preparar fàcilment i que resultés econò$\mathrm{mic}^{34}$. El pla dietètic monàstic ha de perseguir, doncs, quatre objectius: dominar les passions de la gola i de la luxúria, estretament interconnectades; ser conseqüent amb la pobresa que s'ha professat; afavorir la pregària i, en general, tota l'activitat de l'esperit; no comprometre la salut del monjo. En quina mesura i com van assolir aquestes metes Benet de Núrsia i els compiladors monàstics hispans dels segles VI i VII?

\section{a. El sistema alimentari comú}

Els monjos normalment efectuaven una menjada al jorn, a l'hora novena, des del començament de la tardor a l'inici de la primavera ${ }^{35}$, quan els dies són més curts que les nits, i dues, a l'hora sexta i a vespres, entre la Pasqua i l'equinocci de setembre ${ }^{36}$, període en què la insolació supera la fosca. L'observança estricta d'aquest horari era preceptiva per a tots els membres de la comunitat i el trencament injustificat n'implicava un correctiu $^{37}$. Només l'arribada imprevista al monestir de viatgers o eclesiàstics, amb qui l'abat ${ }^{38}$ o el conjunt dels monjos ${ }^{39}$, en senyal de cortesia,

\footnotetext{
${ }^{34}$ Instituiones, 5, 23; cit. G.M. ColombÁs, Comentario, "La Regla de San Benito", p. 426.

${ }^{35}$ Regla de San Benito, p. 139. SAN IsIDORO, Regla, p. 106. SAN Fructuoso, Regla de monjes, p. 141

36" A sancto Pascha usque Pentecosten ad sextam reficiant fratres et sera cenent. A Pentecosten autem tota aestate.....ad sextam prandeant" [Regla de San Benito, p. 138]. "In refectione monachorum, a diebus Pentecostem usque ad autumni principium, tota aestas, interdiana prandia inuitet; reliquum tempus suspendat prandia; cena tantum adponatur" [SAN ISIDORO, Regla, p. 106]. A la Regla de Compludo no apareix cap referència al sopar però, quan Fruitós de Braga hi estableix l'horari del treball manual, especifica que la comunitat, durant la primavera i l'estiu, dinarà normalment a sexta [Regla de monjes, pp. 143-144]. De la llarga durada de la insolació durant aquests mesos i de l'exemple de la norma de Montecassino, sembla que hom en pot deduir que, entre la Pasqua i l'equinocci de tardor, els monjos galaics, llevat de les jornades penitencials, també sopaven a vespres, en contra d'allò que sostenia algun dels panegiristes regionals de San Fruitós [A. VIÑAYO, San Fructuoso de Braga. El hombre, el fundador, el Santo, "San Fructuoso y su tiempo", León, Diputación Pronvincial, 1966, p. 228 i 231].

${ }^{37}$ La Regla de San Benito, p. 142. SAN ISIDORO, Regla, pp. 104 i 114-115. SAN FRUCTUOSO, Regla de monjes, p. 157.

${ }^{38}$ Regla de San Benito, pp. 155-156.
} 
compartien els aliments, podia alterar aquesta rigidesa funcional del refectori. Complimentar els hostes era un deure tan important per a una comunitat monàstica que justificava l'alteració transitòria del ritme alimentari. Fora de les hores convingudes, no era permès als ascetes menjar ni beure res ${ }^{40}$. Només amb motiu d'una indisposició podia l'abat autoritzar un monjo a efectuar una beguda abans de la refecció, mai, emperò, a la vista dels altres membres de la comunitat, per no estimular-los la set ${ }^{41}$

El dinar quotidià, a la majoria de cenobis, es componia de dos plats d'hortalisses i de llegums cuits, més un de tercer de fruita o de verdures tendres crues, si se'n disposava ${ }^{42}$ :

Sufficere credimus ad refectionem cotidianam tam sextae quam nonae, omnibus mensis, cocta duo pulmentaria, propter diversorum infirmitates, ut forte qui ex illo non potuerit edere, ex alio reficiatur. Ergo duo pulmentaria cocta fratribus omnibus sufficiant et, si fuerit unde poma aut nascentia leguminum, addatur et tertium ${ }^{43}$.

La sal, el vinagre i l'oli potenciaven sistemàticament el sabor de potatges, minestres i amanides ${ }^{44}$.

\footnotetext{
${ }^{39}$ SAn Fructuoso, Regla de monjes, p. 157

${ }^{40}$ Regla de San Benito, pp. 142-143. SAN Isidoro, Regla, pp. 106 i 116. San Fructuoso, Regla de monjes, pp. 143, 147 i 153.

${ }^{41}$ SAN IsIDORO, Regla, p. 106.

${ }^{42}$ L'existència sistemàtica d'un hort dintre l'àmbit de la clausura, conreat pels monjos, en devia assegurar, a la gran majoria de monestirs, un abastament continuat al llarg de l'any.

${ }^{43}$ La Regla de San Benito, pp. 135-136. Els benedictins que gaudien de bona salut devien menjar els dos plats cuits; aquells a qui la malaltia o la complexió en desaconsellaven un, podien rescabalar-se servint-se més quantitat de l'altre. La composició de l'àpat principal del dia, a les comunitats masculines de la Bètica, era pràcticament idèntica a l'establerta per Benet de Núrsia: "in utrisque temporibus refectio mensae tribus erit pulmentis; olerum scilicet et leguminum; et si quid tertium fuerit idem pomorum" [SAN ISIDORO, Regla, p. 106]. Força menys explícit, Fruitós de Braga només disposa que els monjos "viuant enim solis oleribus et leguminibus" [Regla de monjes, p. 142]

${ }^{44} \mathrm{Malgrat}$ que les cinc regles analitzades no esmenten els dos primers condiments, sabem per altres fonts coetànies, com Joan Cassià, que entraven a la dieta ordinaria dels monjos, fins i tot en l'estreta i sòbria dels ascetes orientals [A. RouSSELLE, Abstinence et continence dans les monastères de Gaule Méridionale à la fin de l'Antiquité et au début du Moyen Age. Étude d'un régime alimentaire et de sa fonction, "Hommage à André Dupont", Montpellier, 1974, pp. 244-246]. Pel que fa a l'oli, la informació és més abundant: l'inclouen al sistema alimentari monàstic tant Joan Cassià $\mathrm{i}$ Paulí de Nola [Ibidem, pp. 241 i 244-246] com Isidor de Sevilla $\mathrm{i}$ Fruitós de Braga [Vegeu infra, nota 76].
} 
Una porció de pa de forment, de l'ordre d'una lliura ${ }^{45}$, acompanyava els plats calents i freds. El pa de cereals secundaris, fins i tot a Galècia, terra poc apta per al conreu del blat, es reservava exclusivament per als excomunicats; el seu consum tenia, doncs, una finalitat expiatòria ${ }^{46}$. Mentre que el conreu, la batuda i la molitja del cereal eren, excepte als monestirs mancats de rendes ${ }^{47}$, feines que corresponien als serfs i als encomanats laics, pastar i coure el pa de la comunitat figurava entre els serveis que els monjos havien d'assumir periòdicament, només n'estaven dispensats els vells ${ }^{48}$. El pa blanc, en una època de contracció de l'àrea rompuda i de retrocés dels forment, era considerat, doncs, entre les comunitats monàstiques com un queviure digne.

\footnotetext{
${ }^{45}$ "Panis libra una propensa sufficiat in die, sive una sit refectio sive prandii et cenae" [ $\mathrm{La}$ Regla de San Benito, p. 136]. La identificació de la lliura utilitzada per l'abat de Montacassino ha donat lloc a una llarga discussió: sembla que no es tractava pas de la lliura romana de 12 unces ni de la mercadera de 16 , sinó d'una d'especial, quelcom més gran, de 18 unces. Que la mesura no era la corrent a Itàlia es desprèn del fet que la comunitat, quan evacua Montecassino, el 577, atacada pels llombards, s'emporta a Roma, segons Paulo Diacono, el codi de la regla i el "pondus panis" i la "mensuram uini" [Historia Longobardorum, IV, 17; cit. A. LINAGE, Los orígenes del monacato benedictino, I, p. 114, nota 117]. El pa, cru, pesava quatre lliures i, un cop cuit, es dividia en quatre parts iguals, cada una de les quals, com a conseqüència de la pèrdua d'aigua experimentada dins el forn, devia pesar no les 18 unces inicials sinó entre 16 i 14, segons la qualitat de la pasta [Epistola Pauli Diaconi ad Carolum regem, "Consuetudines monasticae", ed. B. Albers, III, Typis Montis Casini, 1907, p 54. Regula Sancti Benedicti Cassinensis comentata, "Patrologiae cursus completus. Series Latina". LXVI, Parisiis, J.P. Migne, 1866, cols. 627-628]. Les quatre regles hispàniques esmentades no especifiquen el pes de la ració diaria de pa; hom pot suposar, tanmateix, que als cenobis de la Bètica, zona molt romanitzada i amb una llarga tradició en el conreu dels cereals, no es devia allunyar gaire del previst per Benet de Núrsia. Mes difícil ho tenien les comunitats galàiques, pel fet que la posició geogràfica hi comprometia l'abastement frumentari [Regla común, pp. 187-188], als refetors de les quals es degueren consumir, si més no transitòriament, pans més petits o foscos que els recomanats pels mestres d'ascetisme mediterranis.

${ }^{46}$ Vegeu infra, nota 200.

${ }^{47}$ On la comunitat havia d'assumir les messes. Per tal com aquesta eventualitat suscitava un palès descontentament entre els monjos, Benet de Núrsia ja havia tractat de consolar-los $\mathrm{i}$ d'eradicar queixes i murmuracions: "si autem necessitas loci aut paupertas exegerit ut ad fruges recollegendas per se occupentur, non contristentur, quia tunc vere monachi sunt si labore manuum suarum vivunt, sicut et Patres nostri et apostoli" [Regla, pp. 147-148]. Els cenobites, com els altres col.lectius socials, han de viure del propi treball; d'aquest principi general, sobre el qual havien reflexionat detingudament els teòrics del monacat antic, Benet en dedueix una conseqüència conjuntural: els ascetes, en determinades circumstàncies, han d'acceptar fins i tot les feines agràries, unes tasques que, malgrat la seva duresa, no són vils ni incompatibles amb la dignitat d'un profés, ni un càstig, sinó el millor mitjà de guanyar-se el propi pa i el dels pobres, i un bon instrument de control de la concupiscència. La necessitat del treball monàstic, doncs, no derivava tant de la necessitat d'evitar l'ociositat, enemiga de l'ànima, com de l'obligació d'atendre la pròpia subsistència i la dels necessitats; recolzava més sobre un principi positiu que no pas sobre una màxima negativa.
}

${ }^{48}$ SAN ISIDORO, Regla, pp. 121. Regla común, p. 186. 
La beguda consistia en una mesura de vi, que oscilava entre l'hemina ${ }^{49}$ de Benet de Núrsia ${ }^{50}$ o els tres gots d'Isidor de Sevilla ${ }^{51}$ i el quart de sextarius de Fruitós de Braga ${ }^{52}$. A les àrees allunyades de la Mediterrània, on la productivitat de les vinyes era molt baixa, com a la Galècia, el vi podia ser substituït per la sidra ${ }^{53}$, bevenda força més assequible -encara que no tan apetitosa- per a les comunitats arrelades a les muntanyes atlàntiques. Les begudes espiritoses, pels seus efectes euforitzants i desinhibidors, suscitaven forts recels entre els experts en ascetisme: Joan Cassià, influït pels teòrics orientals, havia sostingut que la vida contemplativa era incompatible amb el vi ${ }^{54}$; Benet de Núrsia, després de lamentar que els monjos haguessin deixat de ser abstemis, en va autoritzar el consum, en atenció a la feblesa dels dèbils, no pas fins a la sacietat sinó tan sols sòbriament ${ }^{55}$; Leandre de Sevilla arribava a proposar que les monges robustes prescindissin completament del vi, el consum del qual, en petites quantitats,

${ }^{49}$ Els 0,2736 1. de la mesura romana [J. GómEZ, Introducció a "L'Art de la cuina" d'Apici, p. 33] semblen insuficients per a cobrir les necessitats hídriques diàries d'un adult que dedica unes quantes hores a feines intel.lectuals i a treballs mecànics, especialment l'estiu. La solució podria raure en el fet que l'esmentada quantitat es referís exclusivament al vi i que aquest, per tal de reduir-ne els efectes euforitzants, fos rebaixat amb un contingent no especificat, però igual o superior, d'aigua, o bé que l'abat de Montecassino emprés una unitat especial, quelcom més gran que la antiga. Sembla confirmar aquesta darrera hipòtesi el fet que la comunitat, quan, atacada pels llombards, es trasllada a Roma, el 577, s'emporta, a més del codi de la Regla, la "mensuram vini", precaució innecessària si aquesta hagués estat una unitat corrent al Lacio [P. DIACONO, Historia Longobardorum, IV, 17; cit. A. LINAGE, Los orígenes del monacato benedictino, I, p. 114, nota 117.]. Els principals comentaristes de la Regla consideren que l'hemina devia consistir en unes 18 unces, que equivaldrien a uns 0,60 I. [Regula Sancti Benedicti comentata, cols. 645 i 649. A. DE VOGÜÉ, La Règle de saint Benoît, 2, Paris, 1964, pp. 677-678. G.M. Colombás, Comentario, "La Regla de San Benito", p. 437].

50"Tamen infirmorum contuentes imbecillitatem, credimus heminam vini per singulos sufficere per diem": La Regla de San Benito, p. 137.

51 "Ternis quoque poculis fraterna reicienda est sitis": Regla, p. 106

52" Per dies singulos, singulis uini potionibus sustententur; ita denuo dumtaxat ut inter quatuor fratribus sextarius diuidatur" [Regla de monjes, pp. 142-143]. Sembla evident que o no es tractava ja de la mesura romana, equivalent a $539 \mathrm{~mm}^{3}$ [J. GómEZ, Introducció a "L'Art de la cuina" d'Apici, p. 33], perquè la ració diària de vi seria només de 0,1351 . i es situaria força per davall de les necessitats d'un adult, fins i tot de vida sedentària, o a aquesta quantitat de vi s'hi afegia un contingent superior d'aigua [Vegeu supra, nota 49].

${ }^{53} \mathrm{La}$ Regla Común recomana privar del consum de "siceram uel uinum" als monjos que abans d'ingressar al monestir haguessin comès pecats molt greus [p. 207]

${ }^{54}$ A. Rousselle, Abstinence et continence, p. 244.

55 "Licet legamus vinum omnino monachorum no esse, sed quia nostris temporibus id monachis persuaderi non potest, saltim vel hoc consentiamus ut non usque ad satietatem bibamus, sed parcius, quia 'vinum apostatare facit etiam sapientes'" [Regla de San Benito, p. 137] 
quedaria restringit a les més febles i a les malaltes, com a medecina ${ }^{56}$. Tots els casuistes coincideixen a considerar la renúncia al vi com una virtut ${ }^{57}$. Les comunitats que, per les condicions del lloc i la manca de recursos, no puguin garantir als seus membres la mesura quotidiana de vi o, fins i tot, n'hagin de prescindir completament, no se n'han de lamentar sinó donar-ne gràcies a $\mathrm{Deu}^{58}$, perquè els ha facilitat el camí de la perfecció espiritual. L'ebrietat és un pecat molt greu per a un monjo $^{59}$, un dels vicis que els abats, combinant "la severitat del mestre i l'efecte del pare", han d'eradicar totalment de les respectives comunitats ${ }^{60}$.

El sopar, quan s'efectuava, devia ser un poc més lleuger que el dinar, cap de les cinc normes analitzades no especifica en què consistia, només la benedictina indica que el majordom, els mesos en què la comunitat faci dues menjades al dia, ha de reservar per a la nit una tercera part de la ració de $\mathrm{pa}^{61}$. Es probable que, tal com estableix la Regla del Mestre ${ }^{62}$, es compongués del plat "cru" i d'unes porcions del pa i del vi sostrets al dinar. Si fos així - i el testimoni d'algun dels primers exegetes del codi, com Hildemar ${ }^{63}$, semblen confirmar-ho-, la segona refecció no implicaria un increment quantitatiu de la dieta del monjo, sinó una distribució cronològica diferent de la ingesta ${ }^{64}$.

\footnotetext{
56 "Senti quam sit fugienda uini sacietas, ut etiam patriarchis scandalo et culpae causa extiterit. Ergo et uirgo quae uirtute corporis uiget, bene faciat, si omnino se a uino abstinuerit. Inualidam vero et imbecillem pro medicinam debet utere uinum, non pro temulentiam": Libro de las vírgenes, p. 58

${ }^{57}$ Regla de San Benito, pp. 83 i 137-138. SAN IsIdoro, Regla, p.106. San Fructuoso, Regla de monjes, p. 106

58" Ubi autem necessitas loci exposcit ut nec suprascripta mensura inueniri possit, sed multo minus aut ex toto nihil, benedicant Deum qui ibi habitant et non murmurent": La Regla de San Benito, p. 138.

${ }^{59}$ SAN LEANDRo, Libro de las vírgenes, pp. 57-58. SAN IsIDORO, Regla, pp. 115-116, SAN FRUCTUOSO, Regla de monjes, p. 154.

${ }^{60}$ Regla de San Benito, pp. 77-78.

${ }_{61}$ "Quod si cenaturi sunt, de eadem libra [panis] tertia pars a cellerario servetur, reddenda cenandis": La Regla de San Benito, p. 136.

${ }^{62}$ G.M. Colombás y I. Aranguren, Comentario, "La Regla de San Benito", p. 435.

${ }^{63}$ Citat a Regula Sancti Benedicti comentata, col. 615.

${ }^{64} \mathrm{Com}$ ho específica, a Traditio super Regulam Sancti Benedicti, el ja esmentat Hildemar: "tantum manducabant ad sextam et seram...quam manducarent ad nonam, quia solummodo illum cibum quem ad nonam manducabant, manducabant ad sextam et seram" [Regula Sancti Benedicti comentata, col 615].
} 
Les racions ordinàries havien estat calculades en funció de les tasques normals dels monjos; quan el treball s'intensificava, el dèficit energètic era compensat amb un suplement nutritiu, la magnitud del qual es deixava a criteri de l'abat ${ }^{65}$.

La vida del monjo hauria de ser sempre, segons Benet de Núrsia, d'una austeritat quaresmal, però, com que escassegen els ascetes amb la força moral suficient per a assolir aquest nivell d'autoexigència, les mortificacions alimentàries s'han restringit a la quaresma ${ }^{66}$ i a un ampli conjunt de dies desigualment repartits al llarg de la resta de l'any. Mentre que la norma de Leandre de Sevilla no estableix el nombre de jornades penitencials, els codis de Benet de Núrsia, d'Isidor de Sevilla i de Fruitós de Braga, molt més rigorosos en aquest aspecte, precisen amb detall els dies en què la comunitat haurà d'alterar a la baixa la dieta ordinària. A Montecassino i als cenobis que seguien la seva Regla, els monjos dejunaven, de la Pentecosta als idus de setembre, els dimecres i els divendres; de mitjan setembre a Pasqua, tots els dies feiners ${ }^{67}$. Els ascetes, als monestirs bètics on s'observava la norma isidoriana, modificaven el règim, de la Pentecosta a l'equinocci de tardor, tres jorns a la setmana; del 24 de setembre a Pasqua, cada dia, exceptuant els diumenges, les festes i la setmana compresa entre Nadal i Cap d'Any ${ }^{68}$. Quelcom més extens podia arribar a ser el calendari de restriccions alimentàries al Bierzo, on la comunitat dejunava, des de la Pentecosta fins al 27 de juny i entre el 6 d'agost i el 13 de setembre, alguns dies a la setmana ${ }^{69}$; del 14 de setembre a Pasqua i els quaranta jorns anteriors a l'esmentat 6 d'agost, festivitat dels Sants Just i Pastor, tots els dies, menys els de precepte ${ }^{70}$. Les feines del camp o unes temperatures massa altes podien eximir totalment o parcial els monjos, si l'abat ho

\footnotetext{
${ }^{65}$ Regla de San Benito, pp. 136.

${ }_{60}$ "Licet omni tempore vita monachi quadragesimae debet observationem habere, tamen quia paucorum est ista virtus, ideo suademus istis diebus quadragesimae omni puritate vitam suam custodire omnes pariter": Regla de San Benito, p. 150.

${ }^{67}$ Regla de San Benito, pp. 138-139.

${ }^{68}$ SAN IsIDORO, Regla, p. 108.

${ }^{69} \mathrm{D}$ 'aquesta vaguetat redaccional, hom pot deduir-ne que era l'abat qui, a cada monestir, en fixava periòdicament el nombre.

${ }^{70}$ SAN Fructuoso, Regla de monjes, p. 156.
} 
considerava oportú, del dejuni ${ }^{71}$. Cada asceta, tanmateix, podia ampliar voluntàriament, en la mesura en què li ho permetés la salut, el conjunt de jornades penitencials vigent al seu monestir, estenent-lo, fins i tot, als dies de festa; només Isidor de Sevilla - coincidint amb Cesari d'Arle ${ }^{72}$ desaconsella dejunar els diumenges, perquè ho considera poc adient amb la remembrança de la resurrecció de $\mathrm{Crist}^{73}$.

En què consistia exactament el dejuni monàstic? Per a Benet de Núrsia, a suprimir el sopar i retardar el dinar de sexta a nona, durant el semestre en què la comunitat efectuava dos àpats al dia, i a endarrerir l'única col-lació a nona, des del començament de la tardor fins al dimecres de cendra, $\mathrm{i}$ fins a vespres, durant la quaresma ${ }^{74}$. Les restrincions alimentàries assolien, a Montecassino, la màxima intensitat en el transcurs dels quaranta dies anteriors a la Setmana Santa, quan, cada monjo, a més de prolongar el dejuni fins a la posta de sol, es privava, voluntàriament i d'acord amb l'abat, d'una part de la col'lación ${ }^{75}$. L'abast de la renúncia no s'estatuïa preceptivament, doncs, per a tota la comunitat, sinó que es deixava a la generositat de cada membre. Isidor de Sevilla i Fruitós de Braga, més pessimistes que no Benet de Núrsia, estableixen que, durant la quaresma, els monjos no tan sols hauran de renunciar al vi i a l'oli, sinó que s'hauran de conformar amb pa i aigua ${ }^{76}$. Al Bierzo, el vi -sempre escàs- desapareixia també de la dieta durant la "quaresma" estival que antecedia la festivitat dels sants Just i Pastor, si més no per a aquells monjos que no haguessin de realitzar treballs feixucs ${ }^{77}$.

\footnotetext{
71 "A Pentecosten autem tota aestate, si labores agrorum non habent, aut nimietas aestatis non perturbat, quarta et sexta feria ieiunent usque ad nonam; reliquis diebus ad sextam prandeant. Quam prandii sextam, si operas in agris habuerint, aut aestatis nimius fuerit, continuanda eri et in abbatis sit providencia" [Regla de San Benito, p. 138]. Pel que fa a la posició del Bràcar sobre aquest tema, vegeu infra, nota 77.

${ }^{72 " N o n ~ l i c e t ~ p e n i t u s ~ i e i u n a r e, ~ p r o p t e r ~ r e s u r r e c t i o n e m ~ D o m i n i . ~ S i ~ q u i s ~ d i e ~ d o m i n i c a ~}$ ieiunaverit, peccat": Regula ad monachos, "Patrologiae Latina", LXVII, Parisiis, J.P. Migne, 1865, col. 1102.

${ }^{73}$ Regla, pp. 107-108.

${ }^{74}$ Regla de San Benito, pp. 138-139.

${ }^{75}$ Regla de San Benito, pp. 139 i 150-151.

${ }^{76}$ SAN ISIDORo, Regla, pp. 106-107 i 108. SAN Fructuoso, Regla de monjes, p. 156.

${ }^{77 " S e r u a n d a}$ tamen abbatis discretio est; et cum eos graui labore praespexerit onerari ad refectionem singulas potiones tribuatur": SAN FRUCTUOSO, Regla de monjes, p. 156.
} 
Per tal que l'excés de mortificació no deprimís els monjos i els incités a abandonar el claustre ${ }^{78}$, les restriccions alimentàries eren compensades per alguns àpats extraordinaris, estratègicament repartits al llarg de l'any. La distribució cronològica dels suplements de la dieta, a la Regla de Montecassino, està més en relació amb el calendari laboral que no pas amb el litúrgic. Benet de Núrsia només preveu explícitament, com a causa de l'alteració a alça del règim quotidià, l'excés de treball. La ració ordinària de menjar i beure garanteix als membres de la comunitat el mínim calòric necessari per a desenvolupar totes les tasques de la jornada; si efectuen feines més feixugues que les normals, l'abat, per tal de neutralitzar el degast físic subsegüent, pot concedir-los un escreix alimentari, sempre petit i compatible amb la sobrietat pròpia de la vida ascètica ${ }^{79}$. En el cas de la beguda, l'increment pot ser degut també a raons estrictaments físiques, com la calor estival ${ }^{80}$. Els suplements nutritius, doncs, no són pas un dret del monjo sinó una concessió de l'abat, el qual, perquè estaven condicionats a la realització de treballs especials, els devia atorgar normalment els dies feiners, tot coincidint amb les èpoques de les messes o de la verema. S'haurien de conformar els monjos, els diumenges, amb la dedicació a la lectura $^{81}$ i la supressió del dejuni? No millorarien quantitativament o qualitativa els potatges, les minestres i les amanides quotidianes, les jornades festives? No es celebrarien, a les abadies benedictines, amb un dinar especial el Nadal o la Pasqua? La carn d'aus, el consum de la qual no estava explícitament prohibit als monjos ${ }^{82}$, apareixeria a taula aquests dies assenyalats? El codi inicial de l'orde no aporta cap mena d'informació respecte d'això. Quelcom més expressius es mostren, en canvi, els teòrics hispans. Isidor de Sevilla, amb una condescèndencia sense paral·lel, arriba

\footnotetext{
${ }^{78}$ Benet de Núrsia, amb la seva fina penetració psicològica, ja recomanava que els abats no fossin extremosos a l'hora d'establir el nivell d'ascetisme de les respectives comunitats, "ne dum nimis eradere cupit aeruginem frangatur vas" [Regla, p. 176].

${ }^{79}$ "Quod si labor forte factus fuerit maior, in arbitrio et potestate abbatis erit, si expediat, aliquid augere, remota prae omnibus crapula et ut numquam subripiat monacho indigeries": Regla de San Benito, p. 136

${ }^{80 "}$ "Quod si aut loci necessitas vel labor aut ardor aestatis amplius poposcerit, in arbitrio prioris consistat, considerans in omnibus ne subrepat satietas aut ebrietas": Regla de San Benito, p. 137.

${ }^{81}$ Regla de San Benito, p. 149.

${ }^{82}$ Regla de San Benito, pp. 136. M. MontanARI, Alimentazione e cultura, pp. 69-70. Vegeu també infra, notes 210-211 i 276-277.
} 
a autoritzar el reforç de les verdures, el dies festius, amb petites quantitats de $\operatorname{carn}^{83}$, a la compra de la qual consigna una part dels ingressos en metàl-lic del monestir ${ }^{84}$. Fruitós de Braga, menys generós, estableix que els monjos han de ser reconfortats, els disabtes $\mathrm{i}$ els diumenges, amb una mesura de vi a la caiguda de la tarda ${ }^{85}$, en les grans solemnitats del calendari litúrgic, amb tres plats cuits i altres tants gots de vi ${ }^{86} \mathrm{i}$, eventualment, amb la incorporació a la dieta del peix de mar o de riu ${ }^{87}$. L'escassetat de vinyes a la Galècia feia el vi força més desitjable que a les riberes mediterrànies, cosa que explica que el Bràcar n'incrementés la petita mesura quotidiana no tan sols els jorns de precepte sinó també les vespres. Pel que fa al peix, vianda d'abstinència entre els laics, el reformador de Compludo, concordant amb Aurelià ${ }^{88}$, l'incorpora a la dieta monàstica com un aliment extraordinari, exquisit, adient per a reforçar l'àpat d'alguns dies festius. El peix, a mitjan segle VII, tot just començava a aparèixer, doncs, a la taula monàstica; no havia esdevingut encara el símbol de la dieta perpètuament quaresmal dels monjos, oposada a la dels laics, als quals era permés el consum de carn ${ }^{89}$.

El formatge i els ous, els altres dos components principals de les col-lacions penitencials seculars, no són esmentats, ni com a possibles suplements extrordinaris, en cap de les cinc regles analitzades. Les principals característiques dels sistemes alimentaris monàstics de la Postantiguitat eren, sens dubte, la sobrietat i la frugalitat, dos trets que els separaven nítidament dels règims dels laics coetanis, si més no dels vigents entre els col·lectius amb un cert nivell de renda.

Els teòrics del primer cenobitisme occidental ${ }^{90}$, conscients que els 105.

${ }^{83}$ "Diebus uero sanctis interdum cum oleribus leuissimarum carnium alimenta": Regla, p.

${ }^{84}$ Regla, p. 119.

${ }^{85}$ Regla de monjes, p. 143.

${ }^{86}$ Regla de monjes, p. 143.

${ }^{87}$ Regla de monjes, p. 142.

${ }^{88}$ Que només n'havia autoritzat el consum "certis festivitatibus, aut quando sanctus abbas indulgentiam facere voluerit": Regula ad monachos, "Patrologiae Latina", LXVIII, Parisiis, J.P. Migne, 1866, col. 393.

${ }^{89}$ M. MONTANARI, Alimentazione e cultura, p. 48.

${ }^{90}$ Com Martí de Tours, Joan Cassià, Oiand de Condat, Sulpici Sever, Paulí de Nola, Patrici, o Colombà. Els monestirs creats per aquests reformadors del segle $\mathrm{V}$ eren encara, tanmateix, com una mena de ciutats, on els monjos vivien en petites cabanes individuals de fusta, 
àpats col-lectius, entre altres avantatges, afavorien la convivència entre els monjos, en facilitaven el control de la bulímia i hi dificultaven les desigualtats alimentàries, van convertir la taula en un àmbit d'intensa significació comunitària i van envoltar el fet quotidià de menjar en comú d'un ritual gairebé litúrgic. Tots els monjos, inclosos l'abat o l'abadessa quan no tenien hostes i presidien el dinar o el sopar conventuals, compartien, tant el dies feiners com els festius, les mateixes col-lacions; els càrrecs, en circumstàncies normals, no implicaven, als monestirs de la Postantiguitat, cap mena de millora quantitativa ni qualitativa de les dietes ${ }^{91}$. Els plats de totes les taules eren exactament iguals i amb els mateixos ingredients, ja que cada monjo rebia una ració idèntica de vianda $i$ de beguda ${ }^{92}$.

La voluntat de menjar tots junts va obligar les comunitats monàstiques a sotmetre els àpats a una rígida regularitat temporal ${ }^{93}$, a crear un espai específic, el refectori, a improvisar uns costums de taula peculiars, força diferents dels creats pels laics.

El refetor va esdevenir una dependència clau, imprescindible, del cenobi, per tal com era l'únic lloc on els monjos podien menjar i beure ${ }^{94}$. Constituïa, junt amb l'església, el dormitori i la sala capitular, un dels elements arquitectònics centrals del monestir ${ }^{95}$. El menjador només s'obria per parar les taules i celebrar les refeccions; durant la resta del dia, romania tancat.

La taula expressa tant la comunitat que constitueixen els monjos com les relacions existents entre ells. La col-locació dels comensals no és, doncs, buida de contingut cultural, arbitrària o capritxosa; palesa el lloc que ocupa cada profés dintre del col-lectiu. Els monjos, d'acord amb la data d'ingrés

\footnotetext{
agrupades entorn d'un oratori i un refetor de pedra; un poderós mur -l'element fort de la primera arquitectura monàstica- encerclava el conjunt i l'aillava del món circumdant. Els primers cenobis no es caracteritzaven, doncs, per un pla organitzat i tendent a la uniformitat, sinó per una estructuració anàrquica i heterogènea de l'espai.

${ }^{9}$ SAN LEANDRO, Libro de las vírgenes, p. 52. SAN ISIDORO, Regla, pp. 104-105. SAN FRUCTUOSO, Regla de monjes, p. 157. Regla común, p. 191.

92" Aequalia quippe erunt mensarum omnium fercula; similimisque alimentis cuncti reficiendi sunt fratres": SAN ISIDORO, Regla, p. 105.

${ }^{93}$ Vegeu supra, notes 35-41

${ }^{94}$ Regla de San Benito, pp. 152-153. SAN ISIDORO, Regla, pp. 105-106 i 115-116. SAN FRUCTUOSO, Regla de monjes, p. 143

${ }^{95}$ Que, sota la influència de Benet de Núrsia, ha començat a esdevenir un sistema d'immobles articulat i compacte, ben adaptat a la vida cenobítica, propici al silenci i a la pau, dues condicions imprescindibles perquè hi arrelés l'autèntic ascetisme.
} 
al monestir ${ }^{96}$, es distribueixen, en grups d'uns deu, per les taules, arranjades al llarg dels murs ${ }^{97}$. L'abat o un representant seu presideix els àpats des d'una taula singular, situada al fons del refectori, entre les dues fileres de taules ordinàries. Els infants i els vells, pel fet de gaudir d'un règim especial $^{98}$, diposen de llocs específics ${ }^{99}$. Si la presència a la taula indica la pertinença a la comunitat, l'expulsió n'evidencia l'exclusió: el membre que incorri en una falta no compartirà, fins que no n'hagi estat absolt, el past amb els seus germans; menjar sol és signe de culpa i instrument d'expiació $^{100}$.

A les hores convingudes ${ }^{101}$, al toc del senyal, els monjos han d'acudir puntualment al refetor ${ }^{102}$ i el porter ha de tancar les portes del monestir, per tal que cap persona estranya no pertorbi amb la seva presència la quietud de la comunitat ${ }^{103}$. Cada profés, un cop dintre del menjador, s'ha de col-locar ràpidament al seu lloc, tot esperant, dret i en silenci, que entri l'abat o el seu delegat. Tot just acabada la benedicció de la taula ${ }^{104}$, els setmaners començaran a servir els plats del dia. Els monjos, al revés dels laics, han de menjar sempre en silenci rigorós, escoltant atentament el lector ${ }^{105}$, per tal de recuperar alhora les forces corporals amb els queviures materials $\mathrm{i}$ el vigor espiritual amb els textos sagrats ${ }^{106}$. Els oients s'abstindran de demanar cap mena d'explicació sobre els passatges llegits al refetor; només el superior, si ho creu oportú, els comentarà, per facilitar-ne la comprensió als subordinats ${ }^{107}$. Els comensals s'han de servir entre si, han

\footnotetext{
96"Locum vero illum semper adtendat quod ingressus est in monasterio": La Regla de San Benito, p. 171.

${ }^{97}$ Regla de San Benito, p. 135. SAN IsIDORO, Regla, p. 104

${ }^{98}$ Vegeu infra, notes 153-172.

${ }^{99}$ La Regla de San Benito, p. 174. Regla común, p. 186.

${ }^{100}$ Vegeu infra, notes 195-200.

${ }^{101}$ Per a l'horari dels àpats comunitaris, vegeu supra, notes 35-41 i 93.

${ }^{102}$ Regla de San Benito, p. 142. SAN IsIDORO, Regla, p. 104.

${ }^{103}$ SAN ISIDORO, Regla, p. 104.

${ }^{104}$ Regla de San Benito, p. 142. SAN Fructuoso, Regla de monjes, pp. 141-142.

${ }^{105}$ Regla de San Benito, pp. 134-135. SAN LEANDRO, Libro de las vírgenes, pp. 34-35. SAN IsIDORO, Regla, p. 104. SAN FRUCTUOSO, Regla de monjes, pp. 141-142.

106"Et sicut illis corporalis cibus refectionem carnis praestat, ita mentem eorum spiritualis sermo reficiat": SAN ISIDORO, Regla, p. 104.

${ }^{107}$ Regla de San Benito, pp. 134-135.
} 
de demanar les coses que necessitin amb signes més que no pas amb paraules $^{108}$, i no s'han d'aixecar ni deambular pel refetor ${ }^{109}$. Els servidors portaran i retiraran els plats de cada taula, tot seguint les instruccions gestuals de qui presideix ${ }^{110}$, i en recolliran amb cura les sobres, que repartiran després entre els pobres ${ }^{111}$. La comunitat, un cop acabat l'àpat, donarà gràcies, dempeus, a la Providència pels aliments consumits ${ }^{112} \mathrm{i}$ abandonarà el refectori en silenci i ordre. El menjador conventual no constitueix, doncs, un àmbit d'esbarjo i de distensió, sinó un espai -com tants d'altres del monestir - de recolliment i de silenci, on els monjos han perseverar en l'autocontrol dels impulsos biològics i emotius, una zona en la qual la comunitat es contempla a si mateixa i els seus membres s'interrelacionen, d'acord amb un rígid codi de costums.

El lector iniciava la seva tasca setmanal el diumenge a mig matí, quan, després de la missa major, sol-licitava a la comunitat que pregàs per ell $^{113}$. Abans de l'àpat conventual quotidià, acumulava forces amb un got de vi amb aigua ${ }^{114}$. Tan prest com l'abat o el seu representant s'havien assegut, emprenia la lectura, a fi que els monjos poguessin començar a menjar. Conclosa la tasca, el lector, després de demanar permís a la presidència, es retirava, a fer la seva refecció amb els setmaners de cuina i els servidors ${ }^{115}$.

L'alimentació és tan important per a un asceta que tots els redactors de Regles en van confiar la preparació i el servei als monjos. Els domèstics laics no tenien accés al pastador ${ }^{116}$, a la cuina $i$ al refectori de la comunitat $^{117}$, àmbits reservats als professos; només els malalts, els vells, el majordom, a les comunitats nombroses, i els ocupats en serveis de major interès

\footnotetext{
${ }^{108}$ Regla de San Benito, pp. 134-135.

${ }^{109}$ San Isidoro, Regla, p. 104. San Fructuoso, Regla de monjes, p. 104.

${ }^{110}$ Vegeu infra, notes 179 i 182-183.

"1'"Quod mensae redundauerit omni cura seruatum egentibus dispensetur": SAN ISIDORO, Regla, p. 106.

${ }^{112}$ San Isidoro, Regla, p. 106. SAN Fructuoso, Regla de monjes, p. 142.

${ }^{113}$ Regla de San Benito, p. 134.

${ }^{114}$ Regla de San Benito, p. 135.

${ }^{115}$ Regla de San Benito, p.131.

${ }^{116}$ Vegeu supra, nota 48, i infra, nota 224.

${ }^{117}$ SAN ISIDORO Regla, p. 106.
} 
estaven exempts de les tasques dimanants de l'alimentació ${ }^{118}$. Els germans s'han de servir mútuament, a fi de fomentar la cohesió interna de la comunitat, d'estrènyer-hi els vincles de caritat. La tasca - com en el cas del lectors'iniciava el diumenge, després de laudes, amb la sol-licitud de la benedicció de la comunitat ${ }^{119}$. Les atribucions dels setmaners consistien a rebre cada dia els aliments del majordom, preparar i tastar ${ }^{120}$ els potatges, les minestres i les amanides, parar la taula ${ }^{121}$, servir els plats i la beguda, recollir-ne les sobres ${ }^{122}$, i tocar els senyals de les hores canòniques ${ }^{123}$. Els dies feiners, abans de començar el servei, rebien un tros de pa i un got de vi, per tal d'acumular forces i evitar queixes; els diumenges i festius, en canvi, en previsió d'una dieta més forta que l'ordinària, efectuaven el servei en dejú124. Aquest suplement alimentari quotidià, concedit per Benet de Núrsia, sembla que no es donava als monestirs del Bierzo ${ }^{125}$. Un cop finalitzat l'àpat comunitari, els setmaners del menjador i de la cuina -ensemps amb el lector - feien la seva refecció, integrada pels mateixos plats que havien servit als seus germans ${ }^{126}$. El dissabte, abans d'abandonar el servei, els setmaners netejaven les dependències, bugadejaven els eixugamans dels monjos, rentaven, amb l'ajut dels entrats, els peus a tots els membres de la comunitat i retornaven, nets, tots els atuells que havien emprat al majordom, que els confiava als entrats ${ }^{127}$.

Els àpats $\mathrm{col} \cdot$ lectius estaven minuciosament regulats, doncs, per un conjunt de preceptes. El trencament de la disciplina alimentària era sancionat amb una excomunió temporal, dos o tres dies de dejuni, treballs complementaris i silenci ${ }^{128}$; la reincidència pressuposava ja la pena d'assots i una

\footnotetext{
${ }^{118}$ Regla de San Benito, p. 130. Regla común, p. 186.

${ }^{119}$ Regla de San Benito, p. 131.

${ }^{120}$ SAN ISIDORO, Regla, p. 106.

${ }^{121}$ SAN ISIDORO, Regla, p. 121.

${ }^{122}$ SAn Fructuoso, Regla de monjes, p. 142. SAN ISIDORo, Regla, p. 106.

${ }^{123}$ SAN ISIDORO, Regla, p. 121.

${ }^{124}$ Regla de San Benito, p. 131.

${ }^{125}$ SAN Fructuoso, Regla de monjes, p. 157.

${ }^{126}$ Regla de San Benito, p. 131. SAN Fructuoso, Regla de monjes, p. 157.

${ }^{127}$ Regla de San Benito, pp. 130-131.

${ }^{128}$ SAN IsIDORO, Regla, p. 106. SAN Fructuoso, Regla de monjes, p. 153.
} 
llarga reclusió a pa i aigua ${ }^{129}$. Els monjos havien d'acceptar, sense queixes, els plats que els eren oferts diàriament al refectori, pensats per a satisfer les necessitats naturals, no pas per a estimular el plaer del menjar ${ }^{130}$. L a gola, en qualsevol de les seves modalitats ${ }^{131}$, era un vici incompatible amb l'ascetisme ${ }^{132}$.

\section{b. Els règims especials}

Aquestes restriccions alimentàries, concebudes per als monjos normals, no s'aplicaven als infants, als vells ni als malalts, que gaudien, per la seva feblesa sistemàtica o transitòria, d'uns horaris i d'unes dietes específics. La normativa ordinària tampoc no regia la taula de l'abat quan compartia els aliments amb els hostes; el deure de complimentar els pelegrins i els visitants obligava a no sometre'ls, durant la seva estada al monestir, al frugal i escàs règim dels monjos, insuficient per a uns viatgers cansats.

Els codificadors monàstics, a l'hora d'establir l'estatut dels nens en el monestir, parteixen explícitament o implícita de dos principis: sempre s'ha de tenir en compte la seva debilitat ${ }^{133}$ i mai no se'ls ha d'exigir un nivell de perfecció idèntic al dels adults, ja que no en posseeixen ni el seny ni les forces físiques. L'aplicació pràctica d'aquest criteri comença per no sotmetre els nois al rigor de la Regla en els àpats ${ }^{134}$, per tractar-los amb sistemàtica condescendència $^{135}$ i permerte'ls menjar abans de les hores senyalades ${ }^{136}$, encara que en menor quantitat que els adults ${ }^{137}$, i per confiar la distribució

\footnotetext{
${ }^{129}$ SAN IsIDORO, Regla", p. 116. SAN Fructuoso, Regla de monjes, p. 153.

130 "Quidquid praesens refectio dederit omnes sine murmuratione percipiant. Neque id desiderent quod edendi uoluptas appetit, set quod naturae necessitas quaerit. Scriptum est enim: 'carnis curam ne feceritis in desideriis uestris'" [SAN ISIDORO, Regla, p. 105].

131 "Triplex est gulae intemperantia: si quod non licet auidius adpetas, si licita quaeque exquisitis impendiis praeparata accuratius quaeras, si tempus edendi licita non sustineas": SAN LEANDRO, Libro de las vírgenes, p. 51.

${ }^{132}$ Regla de San Benito, pp. 83 i 136. SAN LEANDRO, Libro de las virgenes pp. $50-52$ i $65-$ 66. SAN ISIDORO, Regla, pp. 93-94 i 105.

133"Consideretur semper in eis inbecillitas": Regla de San Benito, p. 133.

134"Nullatenus eis distrisctio regulae teneatur": Reg!a de San Benito, p. 133.

${ }^{135}$ Regla de San Benito, p. 133.

${ }^{136}$ Regla de San Benito, p. 133. SAN IsIDORO, Regla, p. 108. Regla común, pp. 182-183.

${ }^{137}$ Regla de San Benito, p. 136.
} 
cronològica i la magnitud de les seves refeccions quotidianes al majordom $^{138}$ o al preceptor, un monjo experimentat, aquest darrer, a qui ha estat assignada la important tasca d'introduir-los en el domini de les lletres i en el conreu de les virtuts ${ }^{139}$. Només els anònims autors de la Regla común ${ }^{140}$, per tal d'alliberar-los del perill de temperaments ascètics massa zelosos o condescendents, es mostren més explícits respecte d'això i disposen que els infants, des de Pasqua al 24 de setembre, faran quatre menjades al dia; durant la tardor, tres; i entre l'1 de desembre i Pasqua, tantes com cregui oportú el majordom. Aquestes concessions específiques tendeixen a garantir un creixement adequat als nois i a no retardar-ne la transformació en adults sans $i$ aptes per a la vida contemplativa ${ }^{141}$. Com ha assenyalat Antonio Linage ${ }^{142}$, la indulgència dels mestres d'ascetisme envers els infants es tradueix més en un horari flexible, en una distribució menys concentrada de la ingesta, que no pas en millores qualitatives de la dieta. Els avantatges, per altra part, queden parcialment compensats amb la disminució de les racions. Del testimoni de la Regla común, on s'especifica que dels recursos econòmics proporcionats pel bestiar es nodreixen els nens ${ }^{143}$, sembla desprendre's, tanmateix, que el seu règim era quelcom més variat que no pas l'ordinari.

L'altre extrem de la vida, la vellesa, quan les forçes físiques i mentals decauen a un ritme creixent, preocupa també als redactors de les regles monàstiques. El règim alimentari normal estava dissenyat a la mesura de monjos adults i sans, i la seva observança estricta plantejava, doncs, problemes nutricionals a partir de determinada edat. Per tal de garantir-los la longevitat $i$ atenuar-los els sofriments propis de la senilitat ${ }^{144}$, els experts en ascetisme concedeixen als ancians un tractament especial, una reducció

\footnotetext{
${ }^{138}$ Regla de San Benito, p. 125. Regla común, pp. 182-183.

${ }^{139}$ SAN ISIDORO, Regla, pp. 121-122.

140. Pp. 182-183.

141 "Ne... crescens priusquam proficiat cadat, et ante intereat quam bonum facere discat": SAN ISIDORO, Regla, p. 108.

${ }^{142}$ La enfermedad, el alimento y el sueño en algunas reglas monàsticas, "Cuadernos de Historia de la Medicina Española", VI (Salamanca, 1967), p. 20

143"Inde recreantur paruuli": Regla común, p. 188.

144 "Ne... senex aetas antequam moriatur deficiat" [SAN IsIDORO, Regla, p. 108]. "Ne fessa aetas ante tempus frangatur" [Regla común, p. 186].
} 
d'exigències i de deures ${ }^{145}$. A més de dormir en una cel·la més àmplia que la normal i ser atesos per servidors joves ${ }^{146}$, el monjos vells, autèntics arxius de saviesa i d'experiència ${ }^{147}$, quan la comunitat efectuï l'àpat a nona, podran dinar a sexta, si ho desitgen ${ }^{148}$, i gaudiran d'una dieta especial, integrada per aliments tendres $\mathrm{i}$ tous $\mathrm{i}$ petites quantitats de carn $^{149}$. Una part dels ingressos en metàl-lic del monestir o dels recursos generats pel bestiar, si més no a Hispània, es destinaven, precisament, a la compra d'aquests queviures especials ${ }^{150}$. Les seves necessitats específiques seran ateses pel majordom ${ }^{151}$ o per l'encarregat de la sacristia ${ }^{152}$.

La salut constitueix un bé inapreciable per a tothom, també per als monjos. Només un asceta sa pot complir bé totes les tasques i exigències de la vida contemplativa. El cenobita no s'ha d'extenuar, doncs, amb mortificacions excessives i ha de procurar recuperar la salut quan l'hagi perduda. La malaltia, una realitat mai descartable en un col·lectiu nombrós, va preocupar els redactors de les primeres regles monàstiques occidentals ${ }^{153}$. Els monjos sans han de tenir cura dels seus germans malalts amb tanta diligència que no trobin a faltar l'afecte dels parents ni les comoditats de la ciutat ${ }^{154}$. L'abat ha de vigilar atentament - cura maxima- per tal d'evitar qualsevol negligència en el servei dels pacients ${ }^{155}$. Els malalts no han contristar els seus curadors amb murmuracions, capricis i exigències injustificades ${ }^{156}$. Com en altres casos anàlegs, les normes intenten compaginar els diversos interessos i actituds dels monjos per tal de salvaguardar l'harmonia interna de la comunitat. Aquests principis van transcendir el terreny de la teoria,

\footnotetext{
${ }^{145}$ Regla de San Benito, p. 133. SAN Isidoro, Regla, pp. 108 i 119. SAN FruCtuoso, Regla de monjes, pp. 162 i 186.

${ }^{146}$ Regla común, p. 162

${ }^{147}$ Ibidem.

${ }^{148}$ Ibidem.

${ }^{149}$ Regla común, pp. 186 i 207.

${ }^{150}$ SAN Isidoro, Regla, p. 119. Regla común, p. 188.

${ }^{151}$ Regla de San Benito, p. 126. SAN ISIDORO, Regla, p. 120. Regla común, pp. 182-183.

${ }^{152}$ SAN ISIDORO, Regla, p. 119.

${ }^{153}$ I algun dels seus comentaristes contemporanis, com A. LINAGE, Enfermedad, alimento y sueño en algunas reglas monásticas, pp. 9-22.

${ }^{154}$ Regla común, p. 184.

${ }^{155}$ Regla de San Benito, p. 133.

${ }^{156}$ Regla de San Benito, p. 132. Regla común, p. 184.
} 
dels projectes, i es van concretar en realitats ben tangibles. Els monestirs van crear un espai exclusiu per als malalts, la infermeria, un àmbit més ampli i confortable que no pas el dormidor ${ }^{157}$, i en van confiar la gestió a un monjo sa, diligent i solícit, l'infermer ${ }^{158}$. Hom va permetre als malalts utilitzar els banys tantes vagades com convingués, per tal com ho feien no pas per afany de plaer sinó com a medecina ${ }^{159}$. Tot seguint la medicina culta de l'època, que considerava la dieta com el principal remei per a qualsevol malaltia, els codificadors monàstics van concedir als malalts un règim alimentari especial, més variat $\mathrm{i}$ atractiu que no l'ordinari: la infermeria no es regia per l'horari del refetor i s'hi servien aliments més delicats $^{160}$, inclosa la carn ${ }^{161}$ d'aus ${ }^{162} \mathrm{i}$, fins i tot, de mamífers ${ }^{163}$. Aquestsmenús reforçats eren, tanmateix, per als malalts, no pas per als seus curadors, que no en podien menjar ni les sobres ${ }^{164}$. Els recursos necessaris per al normal funcionament de la infermeria eren aportats pel majordom ${ }^{165}$, que destinava a la compra d'aliments especials una part dels ingressos en metàl $\cdot l^{1} c^{166}$, a la Bètica, o dels recursos proporcionats per les periòdiques vendes de bestiar, llana o formatge, a la Galecia ${ }^{167}$.

Rebre, honrar i festivar els pelegrins i els visitants va ser una de les virtuts més conreades pels cenobites, des dels orígens del monacat. Benet de Núrsia ${ }^{168} \mathrm{i}$, en menor grau, Isidor de Sevilla ${ }^{169}$ i Fruitós de Braga van ser dignes hereus d'aquesta tradició. Acollir un pelegrí equival a hostatjar Crist en persona. D'aquest principi dimana l'obligació de rebre, en les

\footnotetext{
${ }^{157}$ Regla de San Benito, p. 132. Regla común, p. 184

${ }^{158}$ Regla de San Benito, p. 132. SAN ISIDORO, Regla, p. 122.

${ }^{159}$ Regla de San Benito, p. 132. SAN LEANDRO, Libro de las vírgenes, p. 59. SAN IsIDORO, Regla, p. 123.

${ }^{160}$ SAN LEAndro, Libro de las vírgenes, p. 56. SAN ISIDORO, Regla, p. 122. SAN FRUCTUOSO, Regla de monjes, p. 157.

${ }^{161}$ Vegeu infra, notes 209, 217, 228, $229: 237-239$.

${ }^{162}$ Vegeu infra, notes 210 i 211.

${ }^{16.3}$ Vegeu infra, nota 210.

${ }^{164}$ San Isidoro, Regla, p. 122. San Fructuoso, Regla de monjes, p. 149.

${ }^{165}$ Regla de San Benito, p. 133. SAN ISIDORO, Regla, p. 120. Regla común pp. 182-183.

${ }^{166}$ SAN ISIDORO, Regla, p. 119.

${ }^{167}$ Regla común, p. 188.

${ }^{168}$ Regla de San Benito, pp. 154-157.

${ }^{169}$ Regla, pp. 123-124.
} 
millors condicions possibles, totes les persones, sense exepceció, que es presentin a la porta del monestir demanant hospitalitat. L'abat i els monjos, a les comunitats benedictines, saludaven amb tota humilitat els hostes, oraven amb ells, els donaven l'òscul de pau, els llegien un passatge de les Escriptures, els donaven l'aiguamans $i$ els rentaven els peus ${ }^{170}$; un cop complerts els ritus més estrictament religiosos, arribava el moment de tractar-los amb tota humanitat, és a dir, procurar-los tot allò que necessitessin $\mathrm{i}$ oferir-lis un bon àpat perquè restauressin les forces. Oferir menjar significa arreu solidaritat, representa convidar algú a formar part de la pròpia $\mathrm{col} \cdot$ lectivitat. En aquest sentit, quan l'abat, sol o amb l'acompanyament dels subordinats, compartia l'àpat amb els pelegrins, els integrava -temporalment- a la comunitat monàstica.

Per tal que els hostes, que mai no falten al monestir i hi arriben a qualsevol hora del dia ${ }^{171}$, no esdevinguin un element pertorbador de la vida ascètica, Benet de Núrsia organitza amb precisió l'exercici de l'hospitalitat. Els confina, en primer lloc, a un espai concret, a l'hostatgeria, amb un nombre de llits suficients, la gestió de la qual confia a un profés experimentat i prudent ${ }^{172}$. Prohibeix als monjos de parlar lliurement amb els visitants, sense un permís específic, a fi d'evitar la penetració d'influències exteriors en la comunitat. Crea una cuina especial, distinta de la conventual, per a que l'abat, trencant el dejuni quotidià, pugui complimentar els invitats ${ }^{173}$, tot compartint amb ells el past, sense alterar el règim ordinari de la comunitat, que seguirà l'horari normal ${ }^{174}$. Dos monjos idonis, exempts d'altres serveis, s'encarregaran d'aquesta cuina al llarg de tot l'any ${ }^{175}$; el majordom $^{176}$ els lliurarà periòdicament els queviures i la llenya necessaris per a garantir-ne un bon funcionament. Separar l'abat dels monjos en un

\footnotetext{
${ }^{170}$ Regla de San Benito, pp. 155-156.

${ }^{171}$ Regla de San Benito, p. 156.

${ }^{172}$ Regla de San Benito, p. 157. Als monestirs de la Bètica i de la Galècia, també hi havia ja habitacions especials per als hostes: SAN IsIDORO, Regla, pp. 123-124; SAN FruCTUOSO, Regla de monjes, p. 149.

${ }^{173}$ "Coquina abbatis et hospitum super se sit, ut incertis horis supervenientes hospites, qui nunquam desunt monasterio, non inquietentur fratres": Regla de San Benito, p. 156.

174 "Ieiunium a priore frangatur propter hospitem, nisi forte praecipuus sit dies ieiunii qui non possit violari, fratres autem consuetudines ieiuniorum prosequantur": Regla de San Benito, pp. 155-156.

${ }^{175}$ Regla de San Benito, pp. 156-157.

${ }^{176}$ Regla de San Benito, p. 125.
} 
moment tan significatiu per a la vida comunitària com la refecció quotidiana constitueix el preu que Benet de Núrsia va considerar oportú pagar per tal que l'exercici del deure de l'hospitalitat no alterés el funcionament intern del monestir, no distragués els monjos de les seves tasques ascètiques.

L'abat disposa, a més de cuina, de taula pròpia. Els seus comensals, en aquestes circumstàncies, són els hostes i els pelegrins. Quan el nombre de comensals externs no sigui suficient, les places vacants podran ser cobertes amb monjos ${ }^{177}$. La invitació de l'abat constitueix, sens dubte, una prova d'estima $\mathrm{i}$, amb tota seguretat, un àpat millor que el comunitari ${ }^{178}$. L'abat i els seus convidats menjaven al refectori comú o en un local específic? El capítol cinquanta-sis de la Regla benedictina fineix recordant a l'abat que ha de deixar sempre amb la comunitat un o dos monjos vells perquè mantinguin l'ordre al refectori ${ }^{179}$, recomanació supèrflua si ell hi fos present. D'aquest passatge i d'altres indicis indirectes espargits per altres capítols de la norma de Montecassino, molts de comentaristes n'han deduït que l'abat, quan menjava amb els hostes, utilitzava una depèndencia específica, situada probablement al costat de la porta del monestir, als confins de la clausura amb el món exterior, o, tal volta, a la hostatgeria, ja en territori laic; en el cas d'emprar el refetor, no ho feia mai a les hores dels àpats comunitaris ni ensemps amb els monjos ${ }^{180}$. Tant la rigidesa temporal com, tal volta, la disciplina espacial, les restriccions quantitatives i qualitatives de la dieta i el silenci preceptiu no s'aplicaven, doncs, a la taula de l'abat, quan aquest la compartia amb els hostes, circumstància que es devia donar molt sovint, especialment als monestirs amb un gran prestigi econòmic o cultural.

Els codificadors hispans només dissenteixen de la norma benedictina, pel que fa a l'acollença dels hostes ${ }^{181}$, en un punt: en la regulació de la taula separada de l'abat, per tal com neguen al superior la facultat d'abando-

\footnotetext{
${ }^{177}$ Regla de San Benito, pp. 161-162.

${ }^{178}$ G.M. Colombàs, Comentario, "Regla de San Benito", p. 454.

179 "Seniorem tamen unum aut duo semper cum fratribus dimittendum propter disciplinam": La Regla de San Benet, p. 162.

${ }^{180}$ G.M. Colombàs, Comentario, "La Regla de San Benito", pp. 454-455.

${ }^{181}$ SAN Isidoro, Regla, pp. 120 i 123-124. SAN Fructuoso, Regla de monjes, p. 149. Regla común, p. 190.
} 
nar el refectori per complimentar els visitants amb un àpat especial ${ }^{182}$; és tota la comunitat la que ha de compartir els aliments, al menjador conventual, amb els nouvinguts, el dia de la seva arribada al monestir, i no pas el cap, en un àmbit específic ${ }^{183}$.

No tots els règims especials eren, tanmateix, més flexibles i amplis que l'ordinari; n'havia de força més rígids i estrets. Tots els mestres d'ascetisme van considerar les sancions alimentàries com un bon mecanisme de correcció de faltes i delictes, en la mesura que reduïa les energies físiques i psicològiques i apaigava les passions. Benet de Núrsia dedica al codex poenalis vuit capítols de la seva norma ${ }^{184}$; Isidor de Sevilla i Fruitós de Braga, cinc ${ }^{185}$; i els abats anònims de la Regla común, tres ${ }^{186}$. Només Leandre presta poca atenció al tema, tractant-lo de passada al capítol disset del seu codi ${ }^{187}$. Per a aquests teòrics de l'ascetisme, tota sanció, gran o petita, té una finalitat correctiva, no vindicativa, ja que persegueix eradicar els vicis i restablir la salut de l'ànima, educar el monjo i salvar-lo. Els seus procediments penals s'adapten a aquesta finalitat, encara que alguns avui ens puguin semblar desproporcionats $\mathrm{i}$, fins i tot, cruels.

El càstig, en la comunitat monàstica, ha de casar sempre tant amb la gravetat de la falta, com amb l'edat i la capacitat d'anàlisi de qui l'ha comesa ${ }^{188}$; l'avaluació d'aquestes circumstàncies correspon a l'abat, en exclusiva, als monestirs benedictins ${ }^{189}$, i amb l'assessorament dels vells,

\footnotetext{
182" Abba citra langoris necessitatem cibos in conspectu pariter cum fratribus sumat. Neque aliut quam ceteri neque cultius ea quae in commune consistunt praeparari sibi quidpiam expectet" [SAN ISIDORO, Regla, pp. 104-105].

${ }^{183 . " Q u o t i e n s ~ a d u e n i e n t e s ~ u e l ~ f i l i i ~ e c c l e s i a e ~ o c c a s i o n e m ~ s i b i ~ n o n ~ a s p e x e r i t ~ o b u i a r e, ~ a b b a ~ u e l ~}$ praepositus fratribus in furtiuam passim, prout uoluerint, comestionem non inquinent" [SAN FRUCTUOSO, Regla de monjes, p. 157]. "Ut cum fratribus aduenientibus hospitibus et peregrinis [abbates] in una mensa communiter uiuant" [Regla común, p. 190].

${ }^{184}$ Els compresos entre el 23 i el 30 [Regla de San Benito, pp. 117-124].

${ }^{185}$ Del 14 al 18 i del 12 al 16, respectivament [Regla, pp. 112-117; Regla de monjes, pp. 151-156]

${ }^{186} \mathrm{El} 14$, el 19 i el 20 [pp. 196-198 i 204-208]

${ }^{187}$ Libro de las vírgenes, pp. 68-70.

${ }^{188}$ Regla de San Benito, pp. 118 i 124. San Is!doro, Regla, p. 116. San Fructuoso, Regla de monjes, p. 153.

${ }^{189}$ Regla de San Benito, p. 118.
} 
a les comunitats galaiques ${ }^{190}$. Per tal com he dedicat un article a aquesta qüestió ${ }^{191}$, aquí em limitaré a resumir-ne les conclusions.

La gola ${ }^{192}$, l'ebrietat ${ }^{193}$, el trencament de l'abstinència de la carn $^{194}$ i totes les altres transgressions de la disciplina monàstica eren sistemàticament sancionades amb penes diverses, entre les quals sobresortien per la seva freqüència les reduccions de la dieta. L'abast i la duració de les restriccions alimentàries depenia de la gravetat del falliment a esmenar.

Les faltes lleus eren corregides amb l'expulsió de la taula conventual i el retard de la col·lación ${ }^{195}$, la sostracció de la ració de vi ${ }^{196}$ o la pèrdua de l'àpat ${ }^{197}$. Aquestes reduccions puntuals de la dieta no impedien al sancionat participar a l'ofici diví ni el dispensaven de les seves tasques ordinàries $^{198}$.

La magnitud de les sostraccions alimenticies s'incrementava en funció de la importància del delicte que sancionaven. Els vicis greus eran eradicats amb llargs dejunis, durant els quals la dieta es reduia a una exigua quantitat de pa i aigua ${ }^{199}$. Els reus convictes de pederastia -el pecat més incomptible amb la vida cenobítica y l'ascetisme- només rebien, durant sis mesos, un petit pa d'ordi i un got d'aigua tres vegades a la setmana ${ }^{200}$. En aquest dos darrers casos, els excomunicats, com a conseqüència d'un règim hipocalòric, no podien desenvolupar gairebé cap activitat física ni intel·lectual; tancats en una cel·la aillada o en la presó, en un sedentarisme permanent, concentraven les poques energies disponibles en el manteniment de les estrictes funcions biològiques.

\footnotetext{
${ }^{190}$ SAn Fructuoso, Regla de monjes, p. 153.

${ }^{191}$ Las restricciones alimenticias como recurso expiatorio en algunas reglas monásticas de los siglos VI y VII, "Estudios en memoria de la Profesora Carmen Orcástegui", Zaragoza, en premsa

${ }^{122}$ Regla de San Benito, pp. 83 i 136. SAN LEANDRO, Libro de las vírgenes, pp. $50-52$ i 65 66. SAN ISIDORO, Regla, pp. 93-94, 105 i 115-116. SAN FruCtuOSO, Regla de monjes, p. 153.

${ }^{193}$ SAN LEANDRO, Libro de las vírgenes, pp. 57-58. SAN IsIDORO, Regla, pp. 115-116, SAN Fructuoso, Regla de monjes, p. 154.

${ }^{194}$ Vegeu infra, nota 232.

${ }^{195}$ Regla de San Benito, pp. 118. SAN Fructuoso, Regla de monjes, p. 152

${ }^{196}$ Regla de san Benito, p. 142.

${ }^{197}$ SAn Isidoro, Regla, p. 104. SAn Fructuoso, Regla de monjes, p. 157.

${ }^{198}$ Regla de San Benito, p. 118. SAN FruCtuoso, Regla de monjes, p. 152.

${ }^{199}$ SAn Fructuoso, Regla de monjes, pp. 153-154 i 161-162. Regla común, p. 196

${ }^{200}$ SAn Fructuoso, Regla de monjes, pp. 154-155.
} 


\section{c. La carn i el vi en les dietes dels monjos}

Els sistemes alimentaris monástics de la Postantiguitat - força concordants- es caracteritzen per un palès vegetarianisme: tots recolzen damunt el pa, els llegums, les verdures i el vi. De provinença vegetal és també l'únic greix de cuina esmentat, l'oli. Aquesta opció dietètica, gens improvisada, és el resultat tant d'una llarga experiéncia ascètica com d'un substrat teòric comú i d'uns contexts culturals força parescuts.

Des de l'inici del monacat oriental, dos queviures van suscitar recels entre els mestres d'ascetisme, la carn i el vi. La primera, pel seu alt contingut en nutrients, que excitava les passions i dificultava el control del cos per la ment; el segon, pels seus efectes euforitzants i desinhibidors, que modificaven els comportaments individuals i les relacions socials; ambdós, per l'apreci de què gaudien entre els poderosos laics, de qui els monjos volien distingir-se palesament. Joan Cassià, bon coneixedor dels codis orientals, considerava encara, al segon quart del segle $\mathrm{V}$, que els ascetes haurien de renunciar completament a ambdós comestibles ${ }^{201}$. El fet que el Cristianisme hagués elegit el vi com a màteria del sagrament de l'eucaristia havia col-locat, tanmateix, en diferent nivell simbòlic els dos aliments i va condicionar-ne la respectiva funció en els futurs sistemes alimentaris, especialment en els del clergat regular. Per tal de diferenciar radicalment la comunió de la resta dels àpats humans, la nova religió havia practicat una marcada transgressió de gènere,"transsubstanciant" el cos i la sang del Redemptor en dos productes vegetals. En l'elecció del pa i del vi, podrien haver-hi influït també tant l'elevat valor que els romans concedien a aquests dos productes com la negativa dels jueus a utilizar-los en els seus ritus sacrats, perquè es tratava d'un aliment fermentat i d'una beguda embriagado$\mathrm{ra}^{202}$. El vi, malgrat els inconvenients esmentats, va gaudir prest de l'apreci dels eclesiàstics, que van contribuir a difondre la viticultura per l'Europa atlàntica. L'hagiografia de la Postantiguitat és plena de sants

\footnotetext{
${ }^{201}$ A. ROUSSELlE, Abstinence et continence, p. 244.

${ }^{202} \mathrm{~J}$. SOLER, Sémiothique de la nourriture dans la Bible, "Annales. Economies. Sociétés. Civilisations", XXVIII (Paris, 1973), pp. 943-955. M. MONTANARI, El hambre i la abundancia, p. 26
} 
evangelitzadors que van començar la cristianització de territoris pagans tot sembrant vinyes $\mathrm{i}$ oferint vi a l'aristocràcia local ${ }^{203}$. El most fermentat va esdevenir la beguda ordinària de tots els estaments i col-lectius socials. El seu consum també es va obrir pas - lentament- als cenobis. Al segles VI i VII, tots els reformadors monàstics occidentals - com ja s'ha exposathavien inclós, no sense una certa malfiança ${ }^{204}$, una mesura de vi en la dieta ordinària dels seus respectius deixebles. Aquesta recuperació, efectiva encara que poc entusiasta, no es va produir en el cas de la carn que, malgrat el deler que suscitava a la resta de la societat, va continuar essent una vianda amb molts més inconvenients que no pas avantatges per als moralistes, especialment per als mestres d'ascetisme.

La carn no apareix a les llistes de queviures adients per a la vida contemplativa que Jeroni ${ }^{205}$, Sulpici Sever ${ }^{206}$ i Paulí de Nola ${ }^{207}$ van incloure a les seves respectives correspondències. La Regla del Mestre va prohibir als ascetes el consum de tota mena de carns, incloses les d'aus, llevat dels dies compresos entre Nadal i els Reis i Pasqua i la Pentecos$\mathrm{ta}^{208}$.

Benet de Núrsia és mostra força més expressiu quan analitza els inconvenients del vi per a la vida ascètica que no quan pondera els desavantatges de la carn. Només esmenta aquesta darrera vianda en dues ocasions: quan defineix l'estatut alimentari dels malalts i i a l'hora de precisar la magnitud de la dieta ordinària de la comunitat. Conscient del valor terapèutic que la medicina coetània li atribuia, disposa que hom serveixi carn als malalts molt febles, per tal que es refacin, i que els sigui sostreta tan prest com acabin la convalescència ${ }^{209}$. Prohibeix terminantment, en canvi, als monjos adults i sans el consum de carn de quadrúpedes i deixa en la indefinició, per als futurs exegetes, si la vianda de volàtils

\footnotetext{
${ }^{203}$ M. MONTANARI, El hambre i la abundancia, pp. 27-30.

${ }^{204}$ Vegeu supra, notes 55-58.

${ }^{205}$ A. ROUSSELLE, Abstinence et continence, p. 240.

${ }^{206}$ A. ROUSSELLE, Abstinence et continence, p. 242.

${ }^{207}$ A. RoussELLE, Abstinence et continence, p. 241.

${ }^{208} \mathrm{~A}$. LiNAGE, La enfermedad, el alimento y el sueño, p. 15.

${ }^{209}$ "Sed et carnium esus infirmis omnino debilibus pro reparatione concedatur; at ubi meliorati fuerint, a carnibus more solito omnes abstineant": La Regla de San Benito, pp. 132133.
} 
podia aparèixer més o menys eventualment, coincidint amb les grans festivitats del cicle litúrgic, a la taula conventual:

Carnium vero quadrupedum omnimodo ab omnibus abstineatur comestio, praeter omnino debiles aegrotos ${ }^{210}$

Solució de compromís - dissimètric- entre l'exclusió total i la inclusió sense restriccions de la carn en la dieta ordinària dels monjos; proposta de formulació deliberadament ambigua que significa una invitació tàcita a la renúncia total, $\mathrm{amb}$ un marge çonsiderable de tolerància, tanmateix, per a les aus ${ }^{211}$.

Leandre de Sevilla és qui més detingudament comenta el paper que la carn ha de jugar dins el règim alimentari de les monges. Comença establint que aquesta vianda, pel seu alt contingut en nutrients, s'hauria de reservar per a aquelles persones que realitzint treballs molt forts, com els fargaires, els guerrers, els manobres i els altres oficis que impliquin un degast físic considerable ${ }^{212}$. Sosté, a continuació, que entre les cenobites, a qui el conreu de l'esperit imposa una vida sedentària, la ingesta de carn i el consum excessiu de qualsevol altre queviure no estan justificats ni són convenients, per tal com fomenten els vicis ${ }^{213}$. Després d'afirmar que les verges només han d'estar sanes, no pas robustes, que el color de la seva cara ha de ser pàl-lid, no pas vermellós, que de la seva boca sols han de sortir pregàries, no pas eructes ${ }^{214}$, i que no han de llegir l'Antic Testament com un text coetani, com una justificació dels àpats abundosos i dels sacrificis de caps de bestiar a Déu, sinó com un testimoni relatiu a una època molt antiga i ja superada ${ }^{215}$, conclou que les monges amb forces suficients per a afrontar les càrregues de l'ascetisme s'han d'abstenir completament de menjar carn, ja que és una pèssima opció alimentar el propi enemic:

\footnotetext{
${ }^{210}$ Ibidem, p. 136.

${ }^{21}$ M. MOnTANari, Alimentazione e cultura, p. 69.

${ }^{212}$ Libro de las vírgenes, pp. 65-66.

${ }^{213}$ Libro de las vírgenes, p. 65.

214 "Virgo tantum sana debet esse, non rigida: pallida gestare ora, non rubentia. Quae suspiria cordis emittat ad Dominum, non ructet cruditates ciborum": Libro de las vírgenes, $\mathrm{p}$. 65

${ }^{215}$ Libro de las vírgenes, pp. 54-55.
} 
Cui tamen suppetit uirtus, a carnibus se abstineat; nam dura est conditio nutrire hostem contra quem dimices ${ }^{216}$

A la infermeria, per a les monges que lluiten contra la malaltia, es serviran, en canvi, plats amb proteïnes i greixos d'origen animal, com a medecines, no pas per a complaure les convalescents ${ }^{217}$. La seva postura, pel fet de no establir cap distinció entre la carn de quadrúpedes i la de volateria, sembla més ferma que no pas la de Benet de Núrsia. Aquesta exigència, estrictament alimentària, del Sevillà és deguda, sens dubte, al fet que escriu per a monges, per a dones que dediquen bona part del dia a l'oració i a la lectura ${ }^{218}$, que no realitzen, tret de cuinar i, tal volta, filar, teixir i confeccionar el vestuari ${ }^{219}$, gaires activitats mecàniques dintre de la clausura ni, molt menys, tasques agràries en el domini ${ }^{220}$. L'administració del patrimoni, la direcció de la fàbrica dels immobles i l'abastament de la comunitat - feines considerades com a masculines pels mestres d'espiritualitat coetanis- eren confiades a un petit conjunt de monjos que habitaven al monestir, per exercir-hi una funció tutelar ${ }^{221}$. La lleugeresa de la dieta devia ser, doncs, la contrapartida, als monestirs femenins, d'una jornada laboral curta i d'un exigu desgast físic.

No pareix agoserat suposar que İsidor de Sevilla coneixia bé el codi del seu germà i que les seves idees ascètiques, com a conseqüència d'un entorn cultural i d'una formació teòrica molt parescuts, no eren gaire distintes. El segon reformador bètic adreça, tanmateix, la seva Regla a una comunitat masculina, als membres de la qual assigna, a més de la pregària

\footnotetext{
${ }^{216}$ Libro de las vírgenes, pp. 65.

${ }^{217}$ Libro de las vírgenes, p. 66.

218 "Diuidantur tibi tempora et officia ut, postquam legeris, ores et, postquam oraueris, legas. Sic alternes perpetim haec dua bona, ut ab iisdem nullo sis tempore otiosa. Quod si aliquid manibus operandum est,... alia tibi legat, ut dum manus uel oculi ciborum intenti sunt operi, pascat aures gratia sermonis diuinis": Libro de las vírgenes, pp. 53-54.

${ }^{219}$ Feines que Isidor [De eclesiasticis officis, "Patrologiae Latina", LXXXIII, Parisiis, J.P. Migne, 1862, col. 801] i l'episcopat bètic, reunit sota la seva presidència, el 619, al II Concili de Sevilla [J. VIVES, Concilios visigóticos e hispano-romanos, Barcelona-Madrid, CSIC, 1963, p. 171], consideraran adients per a les monges, però que no apereixen esmentades al codi de Leandre, redactat unes quantes dècades abans. p. 81 .

${ }^{220} \mathrm{~A}$. LINAGE, La condición social y el régimen laboral, pp. 5-8. IDEM, El ideal monástico,

${ }^{221} \mathrm{~J}$. VIves, Concilios visigóticos, pp. 170-171. J. ORLANDIS, La Iglesia visigótica, p. 251.
} 
i del treball intel-lectual, el conreu directe de l'hort ${ }^{222}$, la producció, als tallers del monestir, d'una part dels articles manufacturats indispensables per a la comunitat ${ }^{223}$, el funcionament de la cuina, del forn i del rebots, la gestió dels negocis, l'administració del patrimoni, la supervisió del conreu dels sementers i de les vinyes, el control de les eres, dels cellers, dels molins i dels ramats, la direcció dels treballs corresponents als domèstics laics - picapedrers, fusters, teixidors, bataners, sastres, sabaters, cerers, moliners, pastors, pescadors i apicultors- i la custòdia i la distribució quotidiana de l'utillatge agrari ${ }^{224}$. El codificador bètic no tan sols es mostra molt exigent quant al nombre de treballs mecànics que assigna als monjos, sinó també quant al temps que els han de dedicar ${ }^{225}$ : els seus horaris laborals, rígids i preceptius, contrasten amb els dissenyats per Fruitós de Braga, força més flexibles ${ }^{226}$. Per poder realitzar totes aquelles tasques, els monjos necessitaven energies, els calia un règim alimentari suficient; la dieta - com ja s'ha exposat-- es componia, els dies feiners, de verdures i llegums, queviures que, a les jornades festives, eren reforçats amb petites quantitats de carn:

Diebus uero sanctis interdum cum oleribus leuissimarum carnium alimenta $^{227}$

Si als monjos malalts se'ls havien de servir aliments més delicats que als sans i aquests gaudien de carn els dies festius, hom pot suposar, malgrat que Isidor no ho especifiqui ${ }^{228}$, que els ingressats a la infermeria en devien menjar força més sovint, si no cada dia.

Una tercera part dels ingressos en metàl-lic del monestir es consignava precisament a la compra de viandes per a millorar tant els àpats festius de la comunitat com els quotidians dels vells i dels malalts ${ }^{229}$. Isidor

\footnotetext{
${ }^{222}$ Regla, p. 100.

${ }^{223}$ Regla, pp. 97-100.

${ }^{224}$ Regla, pp. 120-121.

${ }^{225} \mathrm{Com}$ molt bé ho ha recalcat A. LINAGE [La condición social y el régimen laboral, pp. 810; El ideal monástico, p. 83].

${ }^{226} \mathrm{~J}$. ORLANDIS, La Iglesia visigótica, pp. 242-244.

${ }^{227}$ Regla, p. 105.

${ }^{228}$ Regla, pp. 122-123.

229" Eadem pecunia in tribus partibus diuidenda est, quarum erit una pro infirmis et senibus et pro aliquid coemendo in diebus sanctis cultius ad uictum fratribus": Regla, p. 119.
} 
de Sevilla sembla mostrar-se més exigent que no pas Benet de Núrsia respecte al treball manual dels monjos, però quelcom menys suspicaç, com a contrapartida, envers el contigut proteínic i gras dels àpats, si més no dels festius. Les divergències podrien ser degudes a contextos socioeconòmics diferents, al fet que, al primer terç del segle VII, els monestirs bètics disposessin de menys pagesos i encomanats laics que no els italians ${ }^{230}$.

Pel fet d'haver estat creada per Déu, la carn no és un aliment danyós, vil o impur ${ }^{231}$, sinó tan sols poc adient per als ascetes. La renúncia sistemàtica a la principal vianda animal, segons Fruitós de Braga, afavoreix la vida contemplativa, cosa que explica que l'excloguii completament de les dietes ordinàries dels monjos $\mathrm{i}$ en castigui severament, amb sis mesos de reclusió, el trencament de l'abstinència:

\footnotetext{
Carnem cuiquam nec gustandi neque sumendi est concessa licentia. Non quod creaturam Dei iudicemus indignam, sed quod carnis abstinentia utilis et apta monachis extimetur....Quod si quis monacus uiolauerit et contra sanctionem regulae usumque ueternum uesci carne praesumserit, sex mensium spatio retrusioni paenitentiae subiacebit ${ }^{2.32}$
}

Els monjos sans, que celebren amb peix les festivitats del cicle litúrgic ${ }^{233}$, només han de menjar viandes fortes - carn de volateriadurant els viatges prolongats, per recuperar-se físicament de les llargues caminades $^{234}$. Per als cenobites, que vivien tancats en els seus respectius monestirs, malgrat que dediquessin una part de la jornada al treball manual ${ }^{235}$, els grans desplaçaments devien implicar un trasbals important, una fatiga sostinguda; es lògic, doncs, que, en unes circumstàncies molt diferents de les habituals, gaudissin d'un règim menys frugal que l'ordinari. La carn d'au entrarà també en la dieta dels malalts ${ }^{236}$.

\footnotetext{
${ }^{230}$ A. LiNAGE, Los origenes del monacato benedictino, I, pp. 280-281.

${ }^{231} \mathrm{Com}$ sostenia el Cristianisme inicial, per diferenciar-se del judaisme i dels seus tabús alimentaris: J. SOLER, Sémiothique de la nourriture, p. 954.

${ }^{232}$ Regla de monjes, p. 142.

${ }^{233}$ Vegeu supra, nota 87.

${ }^{234}$ Regla de monjes, p. 142.

${ }^{235} \mathrm{~A}$. LINAGE, La condición social y el régimen laboral, p. 10.

236"Uolatilium esibus infïmi sustentur": Regla de monjes, p. 142.
} 
Els anònims autors de la Regla común preveuen també una presència sovintejada, si no quotidiana, de la carn als àpats que es servien a la infermeria ${ }^{237}$. La vianda animal només estarà completament vetada -com el vi o la sidra - als monjos que haguessin comès pecats molt greus abans de l'ingrés al claustre; en cas de debilitat manifesta, per malaltia o vellesa, l'abat, després d'examinar les circumstàncies personals, podrà autoritzar, tanmateix, la inclusió de la carn en la seva dieta ${ }^{238}$. D'una lectura literal d'aquest passatge de la regla, hom pot deduir-ne que els compiladors galaics no excloïen completament la possibilitat que els professos sans, en circumstàncies molt especials, poguessin menjar carn. Els recursos necessaris per a aquestes millores del règim ordinari s'obtindrien del bestiar ${ }^{239}$. Malgrat que els ramats d'ovelles en garantien un abastament continuat, la carn ocupava, doncs, una posició molt perifèrica dins el règim alimentari dels monjos del Bierzo, el centre del qual corresponia a les verdures, als llegums, al pa i al vi. El codi monàstic col·lectiu no parla, ni de passada, d'un altre important aliment d'origen animal: el formatge. Com cal interpretar aquets silenci? Com una prohibició implícita o com una autorització tàcita? El rigor de la norma galaica envers els ascetes, superior en molts d'aspectes al de les coetànies ibèriques, sembla aconsellar decantarse per la primera opció. Si fos així, perquè els ramats proporcionessin els recursos econòmics per a alimentar la comunitat durant nou mesos l'any $\mathrm{i}$ per reforçar les dietes quotidianes dels vells, del malalts $i$, tal volta, dels infants $^{240}$, els cenobis haurien d'haver organitzat, en aquestes àrees perifèriques d'Hispània, "in ista ultimae extremitatis occiduae partis confinia"241, un sistema d'intercanvis, de mercats locals periòdics, que els permetés tant donar sortida als animals, al formatge i a la llana com adquirir cereals o vi, provinents probablement de les valls del Duero i del Minyo. Situats a la divisòria muntanyosa d'ambdues conques atlàntiques, Dumio i

\footnotetext{
237" Cibi tamen quibus reficiantur teneri et molles ex industria ab ebdomadariis coquantur et carnes et uinum, propter imbecillitatem, moderate eis praebeantur": Regla común, p. 186

${ }^{238}$ Regla común, p. 207.

${ }^{239}$ Que jugava un paper decisiu en l'economia dels monestirs del nord-oest ibèric: vegeu supra, notes 45 i 143 , i infra, nota 240.

${ }^{240}$ Regla de monjes, pp. 187-188.

${ }^{241}$ Com la designa Valeri del Bierzo a De genere monachorum, citat per J. ORLANDIS, Estudios sobre instituciones monásticas, p. 47
} 
les seves filials devien animar encara, a mitjan segle VII, uns circuits comercials d'abast supracomarcal, regional a Galècia.

\section{d. Rerafons clàssic i patrístic de la dietètica monàstica}

L'alt grau de concordança existent entre les prospostes alimentàries de les esmentades cinc regles - concebudes, entre el 550 i 670 , a la Campània, a la Bètica i a la Galècia, tres àrees aleshores força allunyadessembla indicar que no responen sols a un mer empirisme local acumulatiu, a l'experiència successiva de diverses generacions d'ascetes aïllats, sinó que deriven també d'uns fonaments teòrics comuns. La primera dietètica monàstica occidental endinsa les seves arrels a les Escriptures, la Patristica i la medicina culta clàssica.

Massimo Montanari, tot partint de la interpretació que ens han deixat del pecat d'Adam i Eva, arriba a la conclusió que per a un ampli sector dels moralistes cristians antics la gola era el primer dels vicis ${ }^{242}$. La seva exegesi del passatge bíblic - força original- conferia un gran interès a l'alimentació, per tal com podia constituir un obstacle decisiu per a la conquesta de la salvació. La qüestió esdevenia, fins i tot, prioritària, en la mesura en què el gust pel menjar era considerat com la primera avinentesa de cessió a l'imperi dels sentits; l'escaiença més perillosa, com a conseqüència del caràcter necessari i ineludible de l'acte - el menjar - que la sol-licita ${ }^{243}$. Un cop activats, per les viandes, els mecanismes del plaer i de la satisfacció sensorial, és molt fàcil introduir-se en la sendera del pecat, precipitar-se per una via cada cop més ràpida devers la perdició. Sobre aquesta connexió causal entre els diversos vicis, que, començant per la gola, condueix successivament a la lúxuria, l'avarícia, la ira, l'accídia, hi va insistir particularment el ja citat Joan Cassià. Per a aquest pensador oriental trasplantat a Provença, entre els vicis "que fan al gènere humà la guerra més despietada", "el primer és la gastrimàrgia, la gola"244.

Si la gola és el primer dels vicis, el dejuni constitueix, doncs, la primera de les virtuts. Només pel camí de les renúncies alimentàries hom pot assolir el control dels sentits, hom pot arribar a aquella humilitat física que

\footnotetext{
${ }^{2+2}$ Alimentazione e cultura, pp. 4-5.

${ }^{243}$ M. MOnTAnari, Alimentazione e cultura, pp. 4-5.

${ }^{2+4}$ Collationes, V,2; cit. M. MONTANARI, Alimentazione e cultura, p. 5, nota 10
} 
constitueix el necessari suport de la humilitat intel·lectual. L'estudi de les Escriptures demostra, segons el seu traductor al llatí, Jeroni ${ }^{245}$, que "per mitjà del dejuni podem retornar a aquell paradís de què vam ser expulsats a causa de la glotonia".

En un context caracteritzat per la pèrdua del sentit de la mesura, de la proporció, per l'afermament d'uns models de comportament basats en el culte a l'excés, per la identificació del poder i la riquesa amb la bulímia i amb el consum de carn, els teòrics del monacat dels segles V i VI -molt influïts encara pels models orientals- conceben com a ideal ascètic un home que menja el mínim possible, que selecciona curosament els aliments d'acord amb les estrictes necessitats biològiques, no pas en funció del plaer que puguin proporcionar-li $i^{246}$, que s'acontenta amb una dieta frugal, que desconfia dels queviures de provinença animal, que tot just ingereix el past imprescindible per a compensar el consum enèrgetic provocat per la pregària, les feines mecàniques $\mathrm{i}$ el treball intel-lectual ${ }^{247}$, magre de $\cos \mathrm{i}$ pàl-lid de cara ${ }^{248}$. D'acord amb una visió pessimista de l'home, aquests mestres d'espiritualitat consideren que els instints són molt difícils de controlar i temen la sensualitat, entesa com a corporalitat, com a imperi dels sentits, com a impuls animal. La perfecció espiritual no és mai gratuïta, és sempre el fruit d'una dura i llarga lluita contra el propi cos i les seves exigències; en aquesta pugna l'alimentació juga un paper clau, per tal com la gola és el primer parany que un asceta ha de sortejar. El segon és la luxúria, en la mesura que ataca la virtut més característica del monjo, la castedat ${ }^{249}$. Totes les regles concedeixen una gran importància a la renún-

${ }^{245}$ Epistulae, ed. I. Hillber, Vindobonae-Lipsiae, 1918, p. 191; cit. M. MonTANARI, Alimentazione e cultura, p. 6, nota 14.

246" Quidquid praesens refectio dederit omnes sine murmuratione percipiant. Neque id desiderent quod edendi uoluptas appetit, set quod naturae necessitas quaerit" [SAN ISIDORO, Regla, p. 105].

${ }^{247}$ Aquesta idea del necessari equilibri energètic trobarà en Isidor de Sevilla el seu formulador més precís: "Tanta cum discretione reficiendum est corpus ut nec nimis abstinentia debilitetur, nec superflua edacitate ad lasciuiam moueatur,... scilicet ut et uitia carnis non praeualeant et uirtus ad ministerium bonae operationis sufficiat" [Regla, p. 105]

${ }^{248}$ Leandre de Sevilla, cap el 580, aconsellarà — com ja s'ha exposat- a la seva germana Florentina que "virgo tantum sana debet esse, non rigida; pallida gestare ora, non rubentia" [Libro de las vírgenes, p. 65].

${ }^{249}$ En la llista dels instruments de perfecció que han d'utilitzar els monjos, la renúncia a la sexualitat ocupa sistemàticament un lloc destacat: Regla de San Benito, pp. 84-85 i 92; SAN FRUCTUOSO, Regla de monjes, p. 151; SAN ISIDORO, Regla, pp. 111-112 i 115; Regla común, pp. 180-181, 193-195 i 202 
cia de la sexualitat, requisit bàsic de l'ascetisme. Benet de Núrsia, després de col-locar entre els instruments de perfecció "desideria carnis non efficere" i "castitatem amare"250, recorda que el monjo no tan sols s'ha de guardar de pecats i de vicis, entre els quals figuren el mals pensaments i els desitjos de la $\operatorname{carn}^{251}$, sinó que, a més, els ha de manifestar, en humil confessió, a l'abat ${ }^{252}$. Leandre de Sevilla inicia la seva reflexió sobre l'ascetisme femení amb un llarg pròleg ${ }^{253}$ destinat a exaltar la virginitat. La negativa a iniciar-se en els plaers de la carn fa les monges semblants als àngels ${ }^{254}$; les transforma en esposes de Crist, el marit més generós, per tal com va entregar com a escreix, no pas béns materials sinó la seva pròpia sang ${ }^{255}$; les restitueix la integritat originària en què van ser creats els primers pares i que van perdre amb el seu pecat ${ }^{256}$; $i$ les fa mares d'una descendència incorrupta, engendradores de virtuts excelses com el pudor, la paciència, la sobrietat, la humilitat, la temperança, la caritat i la castedat ${ }^{257}$. El seu germà Isidor recomana a l'asceta que, quan sigui sacsejat per l'impuls sexual, contraataqui amb l'oració i confessi al superior el desig que l'agita ${ }^{258}$.

El cos, tanmateix, té les seves exigències, especialment quan és jove, i l'esperit no sempre pot exercir sobre ell un control complet, com ho demostren les pol-lucions nocturnes. El Sevillà estableix que el monjo, quan pateixi una pulsió sexual, n'ha d'assumir la culpa, l'ha de declarar sense trigança a l'abat $\mathrm{i}$, tot l'endemà, s'ha de mantenir allunyat de l'església, purificant-se amb l'aigua i amb les llàgrimes ${ }^{259}$. Fruitós de Braga adopta una actitud parescuda davant les descàrregues involuntàries de la sexualitat, però, més rigorós que no Isidor, preveu que la purificació podrà incloure,

\footnotetext{
${ }^{250}$. Regla de San Benito, pp. 84-85.

${ }^{251}$ Ibidem, pp. 84 i 92.

${ }^{252}$ Ibidem, pp. 96-97.

${ }^{253}$ Libro de las vírgenes, pp. 21-37.

${ }^{254}$ Ibidem, p. 23.

${ }^{255}$ Ibidem, pp. 24-25.

256 "Reparate castimoniae in uobis retentaculo, o uirgines, quod perdiderunt in paradiso primi homines": Libro de las vírgenes, p. 27.

${ }^{257}$ Ibidem, p. 35.

${ }^{258}$ Regla, p. 112.

${ }^{259}$ Regla, p. 111-115.
} 
a més de l'aigua i les llàgrimes, oracions, mortificacions i expiacions ${ }^{260}$. Els abats de la congregació de Dumio insisteixen també en el fet que el monjo ha d'aprendre a dominar els instints del $\cos ^{261}$, n'ha d'eradicar la tendència natural a la fornicació ${ }^{262} \mathrm{i}$ no ha de confiar mai en la seva castetat passada, perquè l'impuls sexual és molt fort i ni els sants ni els savis n'estan exempts ${ }^{263}$.

Menjar molt, segons la dietètica grecollatina, provoca un excés d'"humors", que inevitablement es tradueix en excitacions sexuals. La cultura mèdica clàssica és assumida pels primers teòrics del monacat occidental, que hi busquen una ferma base científica per al seu pensament. Oribassi, el segle IV, recomanava als impotents augmentar la dieta ${ }^{264}$. Es difícil no veure una reminiscència de les seves teories en Isidor de Sevilla -el compilador tardà, a les "Etimologies", d'una part considerable de la literatura científica romana- quan justifica, a la seva Regla, la necessitat de les restriccions alimentàries amb la certesa que "la sacietat del ventre excita prest la luxúria de la carn; aquell qui reprimeix la passió de la gola domina indudablement els moviments de la lascivia"265. El monjo, segons el Sevillà, "ha de reprimir la passió de la gula i mortificar-se amb la virtut de l'abstinència, per tal de dominar les passions"266. Idees parescudes es poden trobar també - amb una formulació quelcom menys precisa - al codi de Leandre de Sevilla ${ }^{267}$ i a la Regla común ${ }^{268}$. Per a Fruitós de Braga, el nexe entre alimentació i sexualitat es tan palès que ni tan sols el comenta.

No totes les viandes estimulen, emperò, la libido; n'hi ha que, afortunadament, la inhibeixen. L'esmentat Oribassi, per combatre la

\footnotetext{
${ }^{260}$ Regla de monjes, p. 151.

${ }^{261}$ Regla común, p. 181.

${ }^{262}$ Regla común, p. 194.

${ }^{263}$ Regla Común, p. 202.

${ }^{264} \mathrm{~A}$. ROUSSELLE, Sesso e società alle origini dell'età cristiana, Roma-Bari, Laterza, 1985, p. 171. M. MONTANARI, Alimentazione e cultura, p. 8.

265" Ex plenitudine uentris cito excitatur luxuria carnis. Qui autem appetitum edacitatis reprimit sine dubio lasciuie motus restringit": Regla, p. 105.

${ }^{266 " G u l a e}$ concupiscentiae deprimat et abstinentiae uirtutibus semetipsum pro estudio dominandarum libidum affligat": Regla, p. 93.

${ }^{267 " S u b i u g a n d a ~ e s t ~ i e i u n i i s ~ c a r o ~ r i g i d a ~ e t ~ e a t e n u s ~ r e f r e n a n d a, ~ u t ~ l e g i ~ m e n t i s ~ e t ~ i m p e r i i s ~}$ animae subiaceta ut ancilla": Libro de las vírgenes, p. 56. p. 180.

268 "Et cogitationes de die in die nascentes cum ieiunio et oratione expellere": Regla común",
} 
impotència, prescrivia no tan sols augmentar la ingesta sinó, sobretot, intensificar el consum de carn, vi, pa sense segó i llegums $\operatorname{secs}^{269}$. Hi ha, doncs, una casuística precisa dels aliments, vinculada a una de les teories fonamentals de la medicina i de la dietètica clássiques, la dels quatre "humors" - calent, fred, humit i sec- que, diversament combinats, constitueixen tots els components de la naturalesa. Per tal com, segons aquests mateixos textos científics, la sexualitat és entesa com un excés d' "humors" càlids i humits, seran les viandes calentes i humides les que desenvoluparan un paper decisiu en la recuperació de les funcions genitals. Els teòrics de l'ascetisme cristià del segle $\mathrm{V}$, que consideren la castedat com un dels requisits primordials per a la unió mística amb Déu, capgirant el plantejament dietètic d'Oribassi, orientaran els monjos cap als queviures freds i secs -hortalisses i llegums verds, fruits i pa integral de cereals secundaris- $\mathrm{i}$ els prohibiran la carn i el vi, perquè predisposen a la luxúria. Aquest rigorisme inicial s'atenuarà, tanmateix, les centuries següents, com a conseqüència de l'ingrés gradual de membres de l'aristocràcia, amb el seu codi alimentari, als monestirs. La centralitat del paper litúrgic que la beguda espiritosa assumeix en la tradició cristiana acabarà conferint-li una imatge positiva i el seu consum, durant la primera meitat del segle VI, prosperarà als refetors monàstics. El procés de recuperació, en el cas de la carn, serà força més lent i complex; les cinc regles analitzades - com ja s'ha exposatconcedeixen diàriament a l'asceta un parell de gots de vi, però només li permeten consumir la vianda d'origen animal en quantitats molt minses i en unes circumstàncies ben determinades, per tal com el cos, segons Leandre de Sevilla, si és alimentat amb carn, esclata en voluptuositat i acaba en la deplorable crueltat de la luxúria ${ }^{270}$. La selecció dels aliments proposada pels mestres d'espiritualitat dels confins de l'Antiguitat i l'Edat Mitjana no era, doncs, improvisada o intuïtiva, sinó fruit de l'experiència i d'uns coneixements científics extrets de la medicina clàssica.

La renúncia monàstica a la carn és, tanmateix, una qüestió intricada, que apunta a diversos objectius i exigeix explicacions múltiples. Darrera de l'exclusió de la vianda animal de la dieta ordinària dels ascetes opera, a més de l'afany de preservar la castedat, una ànsia de mortificar el cos, tot 8-9.

${ }^{269}$ A. Rousselle, Sesso e società, p. 171. M. MontanARI, Alimentazione e cultura, pp.

${ }^{270}$ Vegeu infra, nota 273. 
privant-lo del plaer de menjar, un "rebuig del fardell de materialitat que llastava l'elevació de l'esperit cap a Déu"271. Les restriccions alimentàries eren una manifestació del despreci del cos i de les seves exigències que el monacat es proposa a si mateix i a la resta de la societat com a model perfecte de conducta ${ }^{272}$. D'acord amb aquesta opció espiritual, abandonar el consum de carn era una de les primeres iniciatives a prendre, per tal com la carn era, per definició, el principal aliment de la carn ${ }^{273}$.

Des del punt de vista cultural, privar-se de la carn significava allunyar-se de l'aliment "normal" dels homes, especialment dels poderosos; constituïa una renúncia certament penosa que, com la castedat, palesava la pertinença a la comitiva dels més propers a Déu. La privació de la carn, com molt bé ha subrallat Massimo Montanari, assumia no tan sols el significat d'una genèrica renúncia al "món", sinó també l'abandonament d'aquell món particular de què molts de monjos provenien, el de l'aristocràcia, caracteritzat pel culte a la força i a la violència ${ }^{274}$; palesava l'adopció d'un model de vida pacífic. També en aquest terreny el comportament alimentari refermava la identitat del grup.

Malgrat els inconvenients de la carn, el seu consum estava tan arrelat, a la Postantiguitat, entre totes les capes socials que els redactors occidentals de normes monàstiques, llevat dels irlandesos, no van adoptar una actitud radical envers d'ella; la solució que es va imposar a la llarga va ser la del compromís, ben palesa ja a la Regla inicial dels benedictins. El fundador de Montecassino només va eradicar completament de la dieta dels monjos sans - com ja s'ha exposat- la carn de quadrúpedes; el seu silenci sobre l'aviram constituïa una autorització tàcita i poc entusiasta de la seva presència eventual a la taula conventual. Aquesta ambigua actitud podria significar, doncs, una invitació insinuada a l'abstenció total, amb un marge substancial, emperò, per a les aus, força superior al que van concedir, mig segle abans, Cesari d'Arle i Aurelià a les seves respectives comunitats ${ }^{275}$.

\footnotetext{
${ }^{271}$ M. MONTANARI, Alimentazione e cultura, p. 64.

${ }^{272} \mathrm{Com}$ mol bé ho ha assenyalat M. MONTANARI: Alimentazione e cultura, p. 64.

${ }^{273 "}$ "Quid poterit caro nutrita carnibus, nisi erumpe ad libidinem, miseraque crudelitate luxuriae debachare?": SAN LEANDRO, Libro de las vírgenes, p. 65.

${ }^{274}$ Alimentazione e cultura, p. 65.

${ }^{275}$ Vegeu supra, notes 72 i 88 .
} 
La distinció que fan els mestres d'ascetisme entre la carn de quadrúpedes i la de volataria respon, també, a causes diverses. La raó més adduïda per a explicar el diferent grau de recel és de natura cosmològica: les aus van ser creades al mateix temps que els peixos i abans que els animals de terra. Aquesta cronologia de la Creació atansava, doncs, els ocells als peixos, malgrat no compartir-ne el medi i la palesa disparitat tant taxonòmica com tèrmica, i els allunyava dels mamífers, rèptils i tots altres animals terrestres. El prestigi que tenien els peixos entre els primers creients ${ }^{276}$, com es depren de la iconografia paleocristiana, s'estenia cap a les aus. La distinció entre totes dues varietats de vianda animal respon també a raons "fisiòlogiques", derivades de la funció instrumental que jugava l'alimentació, als monestirs, en la contenció de la sexualitat. Segons la medicina científica clàssica, la carn d'aviram era més lleugera i digestiva que no la de quadrúpedes, enfarfegava menys l'organisme i no estimulava tant la líbido ${ }^{277}$. Pel fet de ser menys "càlida" que la dels mamífers, el seu consum no dificultava tant la preservació de la castedat.

La relació dels ascetes amb la carn, l'aliment més apreciat pels laics, independentment de la seva respectiva extracció social, va ser, doncs, complexa; va respondre a causes de natura molt diversa, totes relacionades amb una opció de vida que donava prioritat a l'esperit, que menyspreava el $\cos \mathrm{i}$ les seves exigències i que havia fet de la castedat, de la renúncia voluntària a l'exercici de la sexualitat, un dels seus principals trets diferencials. Els plantejaments dietètics dels reformadors monàstics dels segles VI i VII, que havien assignat a l'alimentació una important funció instrumental, no obeïen a la mera intuició, sinó que estaven fonamentats tant en un coneixement profund de la medicina clàssica i de la Patrística com en una llarga experiència de lluita pel domini de les passions.

\section{CONCLUSIONS}

Com a conseqüència de l'esfondrament de les estructures romanes, de la caiguda de la mà d'obra esclava, de la instal-lació dels pobles germànics en extensos territoris imperials i de l'ascens d'una nova aris-

\footnotetext{
${ }^{276}$ Ben analitzat per Massimo MONTANARI a Alimentazione e cultura, pp. 48-49.

${ }^{277}$ M. MONTANARI, Alimentazione e cultura, p. 70.
} 
tocràcia militar terratinent, es van produir, entre els segles V i VII, a l'Occident, un conjunt de canvis importants en el paisatge, en l'estratègia d'explotació de l'espai i en els models del consum alimentari.

La influència creixent de les pautes culinàries de l'aristocràcia germànica sobre el conjunt de la societat, l'avanç de la ramaderia i de la caça a càrrec de l'agricultura i l'esgotament de la dietètica i de la medicina clàssiques van provocar una sobrevaloració de la carn i del llard, la pèrdua de protagonisme del pa i de l'oli, i la multiplicació i diversificació dels components -especialment els de provinença animal- dels principals sistemes alimentaris.

L'estima per la carn va assolir la cota màxima entre els restringits cercles dels poderosos, de la incipient noblesa altmedieval, que proposa com a model un home fort, valent i generós. Per als nous militars, la vianda animal esdevingué una necessitat més psicològica que biològica, es va convertir en el símbol mateix del vigor físic i del poder, en la manifestació gastronòmica d'una mentalitat violenta i sensual que caracteritzava la cultura i la manera de viure dels potentes.

L'únic col·lectiu que no va participar d'aquesta nova unaminitat alimentària va ser el dels monjos. En un context presidit per la pèrdua del sentit de la mesura, pel culte a l'excés, els codificadors monàstics van proposar com a paradigma moral un home que gairebé no menjava, que seleccionava curosament els aliments d'acord amb les estrictes necessitats biològiques, que havia renunciat als plaers de la taula, i que conreava el dejuni i l'abstinència. Als refetors conventuals de la Postantiguitat van prosperar, doncs, uns plantejaments dietètics radicalment oposats als vigents als menjadors aristocràtics. El règim dels cenobites havia de facilitar el control dels impulsos del cos, especialmemt de la gola i de la luxúria, havia d'afavorir l'oració i l'activitat espiritual i havia de requerir pocs recursos econòmics.

D'acord amb una visió pessimista de l'home, Benet de Núrsia, Isidor de Sevilla o Fruitós de Braga consideren, entre el 550 i el 650, que els instints són molt difícils de controlar i temen la sensualitat, entesa com a imperi dels sentits, com a impuls animal. La perfecció espiritual, segons aquests teòrics de la vida contemplativa, no es mai gratuïta, és sempre el fruit d'una dura i llarga lluita contra el propi cos i les seves exigències; en aquesta pugna l'alimentació juga un paper clau, per tal com la gola és el primer parany que un asceta ha de sortejar. El segon és la luxúria, en la mesura que ataca la virtut més característica del monjo, la castedat. La 
renúncia parcial i reglamentada als aliments constitueix el mètode més directe $\mathrm{i}$ eficaç per a intervenir sobre l'equilibri psicofisiològic de les persones i decantar-lo cap a la continència sexual.

La mitificació de la castedat - requisit primordial per a la unió mística amb Déu i senyal d'identitat de l'asceta - havia allunyat els monjos dels segles IV i V dels queviures forts, com la carn o el vi, que, segons la medicina clàssica, excitaven la líbido, i els havia orientat cap el pa, les verdures, els llegums $i$ els fruits, que la inhibien. Els primers trets diferencials de les dietes monàstiques van ser, doncs, la frugalitat i el predomini dels components de natura vegetal. La centralitat del paper litúrgic assignat, des dels inicis de la tradició cristiana, a la beguda espiritosa li confereix una imatge cada cop més positiva i el seu consum prospera, tanmateix, als refetors monàstics. El procés de recuperació, en el cas de la carn, serà, en canvi, força més lent i complex i anirà estretament vinculat a l'ingrés creixent, durant l'Alta Edat Mitjana, de mebres de l'aristocràcia militar al claustre.

Els contiguts dietètics de les cinc Regles analitzades presenten molt més punts de coincidència que no pas de divergència. La dieta ordinària dels monjos era exclusivament vegetariana i estava integrada, tant a Hispània com a Itàlia, per llegums, verdures, pa i vi. La sal, l'oli i, tal volta, el vinagre milloraven els sabors de potatges, minestres i amanides, els tres plats que sortien gairebé cada dia a taula. Les tasques feixugues o la duresa del temps podien implicar un suplement alimentari quantitatiu, no qualitatiu, a criteri de l'abat. Els diumenges $\mathrm{i}$ les festivitats trencaven periòdicament la monotonia alimentària amb modificacions puntuals del règim; aquestes novetats, tanmateix, consistien més en augments de les racions o del nombre de menjades que no pas en la incorporació de queviures més selectes a la dieta. Els únics reforços qualitatius previstos per als àpats de festa són el peix, al Bierzo, i la carn, a la Bètica. Les nombroses jornades penitencials no implicaven tampoc importants pèrdues qualitatives, sinó la supressió del sopar o el retard de l'àpat únic, que passava de sexta a nona. Durant la quaresma, la mortificació s'accentuava i repercutia a la taula conventual, que només es parava a vespres i de la qual desapareixien, a Hispània, tots els queviures quotidians, exceptuant el pa i l'aigua; entre els benedictins, a Itàlia, les renúncies alimentàries quaresmals no eren col-lectives, sinó individuals i personalitzades. Aquesta normativa alimentària, que concedia a l'abat, especialment en les comunitats que es guiaven pel codi de Montecassino, importants atribucions, tan sols era preceptiva per als monjos 
adults i sans; els malalts, els vells i els infants gaudien de règims especials, més flexibles, heterogenis $\mathrm{i}$ amb un continguts de proteïnes i greixos quelcom més alt.

El valor expiatori de les restriccions alimentàries era un altre dels principals punts de concordança entre els mestres d'ascetisme analitzats. La sostracció de nutrients, en la mesura que reduïa les energies físiques i psicològiques, apaivagava les passions $\mathrm{i}$ facilitava el redreç moral dels pecadors. La gola, l'ebrietat, el trencament de l'abstinència de carn i totes les restants transgressions de la disciplina alimentària implicaven, entre altres penes, l'expulsió de la taula conventual i la corresponent contracció de la dieta. Les sancions, en aquest terreny, podien anar des del menyscapte d'un àpat, per haver arribat tard a taula, fins a sis mesos de dejuni rigorós, a pa d'ordi i aigua tres vegades a la setmana, en el cas de pederastia.

L'actitud davant la carn és, en canvi, quelcom més diferenciada. Tots la consideren una vianda poc adient per a la vida contemplativa. Leandre de Sevilla en prohibeix totalment el consum a les monges sanes. Fruitós de Braga reserva la d'aviram per als professos sotmesos a un gran degast físic, per als ascetes que han d'efectuar llargs viatges. La Regla común en preveu tàcitament una presència molt escadussera als menús extraordinaris. Benet de Núrsia exclou explícitament la de quadrúpedes dels àpats conventuals, fins $i$ tot dels festius, i no es defineix respecte a la d'aus, lapsus que permet considerar que en tolera eventualment el consum. Isidor circumscriu el vet de la carn als dies feiners i n'autoritza la inclusió, en petites quantitats, als potatges de les jornades festives. La unaminitat torna a reaparèixer, emperò, a l'hora de definir els règims especials: pel seu poder regenerador, pels seus efectes terapèutics, pel seu alt contingut en nutrients, cap dels teòrics de l'ascetisme analitzats no considera oportú privar de la carn els malats i els vells; pel que fa als infants, l'aquiescència no és explícita, encara que no manquen, en cap dels codis, els indicadors d'una tolerància tàcita.

El consum de la carn estava, tanmateix, tan arrelat socialment que els reformadors monàstics occidentals de la Postantiguitat, exceptunat-ne els irlandesos, no van adoptar una actitud radical respecte a la seva absència dels refetors. Van invitar el seus seguidors a abstenir-se'n totalment, concedintlos, emperò, un marge substancial de tolerància per a la vianda de volateria. La carn no hauria de ser, per als monjos dels segles VI i VII, un aliment sinó una medecina o, en el millor dels casos, un premi, una compensació puntual pels nombrosos sacrificis que exigia la vida contemplativa. 
La distinció introduïda pels mestres d'ascetisme entre les viandes de quadrúpedes i les d'aus obeïa a causes de natura molt diversa, cosmològiques, fisiològiques $\mathrm{i}$, fins $\mathrm{i}$ tot, psicològiques. L'admissió eventual de l'aviram a les cuines conventuals es devia al fet que la seva carn era més parescuda a la dels peixos que no a la dels mamífers, més fàcil de digerir, menys "afrodisíaca" i sangnosa que la dels animals terrestres.

La renúncia monàstica a la carn és, tanmateix, una qüestió complexa, que apunta a diversos objectius i exigeix explicacions múltiples. Darrera l'exclusió de la vianda animal batega també un afany de mortificar el cos, tot privant-lo d'una de les principals fonts de plaer, el menjar. Les restriccions alimentàries eren una manifestació del despreci del cos i de les seves exigències que el monacat, als confins de l'Antiguitat i l'Edat Mitjana, es va proposar a si mateix i a la resta de la societat com a model perfecte de conducta.

Privar-se de la carn significava allunyar-se de l'aliment "normal" dels poderosos, palesava una renúncia al món de l'aristocràcia, d'on provenien molts dels monjos, un rebuig al culte de la força i de la violència, representava l'elecció d'un model de vida pacífic.

L'exclusió de la dieta ordinària d'una vianda normal i de fàcil obtenció, de consum aleshores molt difós i prestigiat entre totes les capes socials, especialment entre la noblesa, va constituir, a l'Occident postclàssic, una opció antiaristocràtica, que postulava un model de vida adaptat a les exigències de l'esperit, no pas del cos. El rebuig de la carn i l'acceptació de la frugalitat van ser una elecció elitista, per tal com, en la mesura que allunyaven la dieta del monjo dels sistemes alimentaris coetanis, esdevenien un element d'autoidentificació, un senyal de pertinença al restringit cercle dels més pròxims a la Divinitat. Les restriccions alimentàries i la renúncia a l'exercici de la sexualitat van ser presentats pels moralistes com els trets distintius i qualificadors de la "santedat". Els monjos proposaven, doncs, a la resta de la societat un contramodel, en la definició del qual l'alimentació jugava un paper clau. El codi alimentari assegurava, també en aquest cas, la identitat i coherència del grup. 


\section{RÉSUMÉ}

Depuis le $\mathrm{V}^{\mathrm{e}}$ siècle, à conséquence de l'effondrement de l'Empire Romain et de l'intallation des peuples germaniques, se produit en Occident un assemblage de changements dans le paysage et dans les modèles alimentaires: la viande et le lard furent revalorisés.

En ce nouveau contexte, seulement le collectif des moines continue se nourrissant avec du pain, de l'huile, des légumes et des verdures. La défiance que les maîtres de l'ascetisme avaient vers les aliments qui provenaient du monde animal était une conséquence de la conviction que une diète forte excitait la gourmandise et la luxure, qui étaient les deux vices les plus incompatibles avec la perfection spirituelle. Se priver de manger de la viande impliquait aussi rejeter le monde de l'aristocrace et ses valeurs. La consommation de la viande était une habitude si établie socialement que les reformateurs monastiques ne osèrent pas adopter une position trop radicale. Ils demanderent seulement aux ascetes adultes et sains de se priver totalement de la viande, quoique leur fût accordé une certaine tolérance pour les volailles.

\section{SUMMARY}

Since the fifth century, as a result of the fall of the Roman Empire and the settlement of Germanic peoples, a lot of changes took place in the landscape and in the patterns of nourishment of the population: meat and lard were revaluated.

In this new context, only the monks kept on feeding themselves with bread, oil and vegetables. The ascetics' mistrust against animal food was a result of their conviction that a strong diet stimulated greed and luxury, both vices opposed to the spiritual perfection. The refusal of meat was equivalent to a refusal of aristocracy and its values.

The habit of eating meat was so generalized that the monastic reformers did not dare to adopt a radical attitude against it. They only invited the adults and healthy ascetics to avoid eating meat completely, but they allowed them to eat poultry. 